\title{
Experimental study of slender concrete-filled elliptical hollow section beam-columns
}

\author{
F. McCann* ${ }^{1}$, L. Gardner ${ }^{1}$, W. Qiu ${ }^{1}$ \\ 1 \\ Department of Civil and Environmental Engineering, South Kensington Campus, Imperial College London, SW7 \\ 2AZ, UK. \\ *Corresponding author. Telephone: +44 79 43525139. Email: finian.mccann@imperial.ac.uk
}

\begin{abstract}
Experiments on concrete-filled elliptical hollow section beam-columns have been conducted to examine their fundamental structural behaviour. A total of 27 specimens were tested -3 stub columns and 24 longer members of varying slenderness. Seven of the tested specimens also contained steel reinforcement. The specimens were loaded in compression, either concentrically or with different major or minor axis eccentricities. Measurements of the applied load, the strains at mid-height, the axial displacement and the lateral deflection at mid-height were recorded. Plots of load against the lateral deflection at mid-height and load against axial displacement are presented for the specimens, along with values of strength index and ductility index. Comparisons have been made between the test results and the provisions of the European Standard EN 1994-1-1:2004 for determining the ultimate load of concrete-filled circular and rectangular hollow section columns. It was found that the predicted resistances are safe
\end{abstract}


for use in the design of concrete-filled elliptical hollow section columns either with or without reinforcement, and loaded either concentrically or eccentrically.

Keywords: composite structures; concrete-filled steel tubes; design of structures; elliptical sections; experimental investigation; tubular sections 


\section{Symbols}

Latin script symbols

$a$

major axis outer radius

$A_{\mathrm{a}} \quad$ cross-sectional area of steel tube

$A_{\mathrm{c}} \quad$ cross-sectional area of concrete

$A_{\mathrm{s}} \quad$ cross-sectional area of steel reinforcement

$b \quad$ minor axis outer radius

$e_{y} \quad$ load eccentricity to the major axis

$e_{z} \quad$ load eccentricity to the minor axis

$E_{\mathrm{a}} \quad$ modulus of elasticity of steel tube

$E_{\mathrm{cm}} \quad$ secant modulus of elasticity of concrete

$E_{\mathrm{s}} \quad$ modulus of elasticity of steel reinforcement

$(E I)_{\mathrm{eff}} \quad$ effective flexural stiffness

$(E I)_{\text {eff,II }} \quad$ effective flexural stiffness taking second-order effects into account

$f_{\mathrm{c}} \quad$ compressive strength of concrete

$f_{\mathrm{s}} \quad$ yield strength of steel reinforcement

$f_{\mathrm{y}} \quad$ yield strength of steel tube

$I_{\mathrm{a}} \quad$ second moment of area of steel tube cross-section

$I_{\mathrm{c}} \quad$ second moment of area of concrete cross-section

$I_{\mathrm{s}} \quad$ second moment of area of steel reinforcement

$k \quad$ design factor to account for second-order effects

$L \quad$ length of specimen

$M_{\mathrm{Ed}} \quad$ design moment 


$\begin{array}{ll}M_{\mathrm{u}, \text { exp }} & \text { second-order inelastic ultimate moment } \\ N_{\mathrm{cr}} & \text { elastic critical buckling load } \\ N_{\text {cr,eff }} & \text { elastic critical buckling load for calculating second-order moments } \\ N_{\mathrm{Ed}} & \text { design axial load } \\ N_{\mathrm{u}, \text { exp }} & \text { experimental ultimate load } \\ N_{\mathrm{u}, \mathrm{EC} 4} & \text { design ultimate capacity of columns according to EN 1994-1-1:2004 } \\ N_{\mathrm{pl}, \mathrm{Rd}} & \text { plastic resistance of cross-section in compression according to } \\ & \text { EN 1994-1-1:2004 } \\ t & \text { steel tube wall thickness }\end{array}$

Greek script symbols

$\chi \quad$ buckling reduction factor

$\Delta \quad$ axial displacement

$\bar{\lambda} \quad$ nondimensional global slenderness

$\rho \quad$ reinforcement ratio

$\omega_{\mathrm{g}} \quad$ initial global imperfection amplitude

$\omega_{\mathrm{u}} \quad$ mid-height lateral deflection at ultimate load 


\section{Introduction}

In recent years, concrete-filled steel tubular (CFST) columns have gained increasing usage and popularity due to a number of benefits that they offer over plain concrete or hollow steel columns. These benefits include greater cross-sectional resistance for the same outer dimensions, greater stability of slender cross-sections, enhanced fire resistances, no requirement for temporary formwork and greater resistance to seismic loads [1, 2]. Having originally found use in bridge piers in the UK in the late 1800s [3], research interest increased from the 1960s onwards [1, 3-6], but significant uptake of the technology was hampered by construction difficulties at the time [7]. With the advent of high strength concrete and more effective and reliable pouring and pumping techniques, there has been a significant increase in the application of CFST columns globally in the past two decades, particularly in China [7]. Research topics concerning CFST elements are varied and include the material modelling of confined concrete [8], fire resistance $[9,10]$ and testing of stub columns [11-14], slender columns [15-17] and stainless steel CFST members [18-20]. A comprehensive review of practical applications of CFST elements is provided in [21].

Previous studies [8-20] into the structural behaviour of CFST sections have focussed on circular, square and rectangular hollow sections (CHS, SHS and RHS, respectively). In the past fifteen years, more attention has been paid to steel elliptical hollow section (EHS) members, which have become of more practical interest due to their introduction and availability as hot-finished products [22], their aesthetic properties and their enhanced flexural properties compared to CHS tubes [23]. Research on steel tubes of 
elliptical cross-section has been extensive in recent years, including the testing and complementary numerical analysis of such members under concentric and eccentric compression [24,25] and in bending [26]. The buckling of steel EHS columns and beams was investigated by [27] and [23, 28], respectively, while local buckling and postbuckling behaviour was examined by [29]. These studies provided a basis upon which design rules for steel EHS members have been formulated [30], including for compressive resistance [24], bending [26], shear [31] and flexural buckling [27]. Prominent examples [30] of the use of steel EHS members in practice include the Zeeman Building at the University of Warwick, the Society Bridge in Scotland and the main airport terminal buildings in Madrid, Cork and London Heathrow.

In the context of concrete-filled elliptical hollow section (CFEHS) members, while the literature is currently fairly limited, previous experimental studies include compression testing of stub columns [32, 33], testing of concentrically-loaded slender columns [34] and eccentrically-loaded columns [35-37]. The behaviour of CFEHS columns in fire conditions was also examined by [37]. In the present study, a total of 27 specimens were tested -3 stub columns and 24 longer members of varying slenderness. Seven of the columns also contained steel reinforcement. The specimens were loaded in compression, either concentrically or with different major or minor axis eccentricities.

The steel EHS members were filled with self-compacting concrete (SCC), which reflects onsite practice where access for vibrating and compacting equipment is restricted [38]. Developed originally in Japan in the 1980s [39], the high degrees of workability and segregation resistance possessed by SCC were needed in the present study owing to the confined geometry of the steel tubes. While the fresh properties of an 
SCC mix are quite different to conventional concrete mixes, the hardened strength is very similar $[40,41]$. Previous investigations of steel specimens filled with SCC include studies on circular and square stub columns [13], CHS tubes in bending [42], CHS columns under eccentric compression [43] and EHS columns under concentric compression [34]. In the present paper, the experimental setups and procedures are first described after which the key test results, including load-lateral deflection curves, loadaxial displacement curves, ultimate capacities and strength and ductility indices are presented. Finally, the results are compared with the provisions of the European Standard EN 1994-1-1 [44] for the prediction of the design resistance of the columns.

\section{Experiments}

In this section, the CFEHS specimens and the procedures employed for conducting the column and beam-column tests are described. Tests on the constituent materials are also outlined. The results of the experiments on the CFEHS members are presented in Section 3.

\subsection{Test specimens}

All 27 test specimens were of the same cross-section $(150 \times 75 \times 6.3$ EHS) but of different lengths in order to assess the effect of varying the nondimensional slenderness $\bar{\lambda}$ which is defined in Section 4.1. The cross-section was chosen to ensure that local buckling did 
not occur during testing of the slender columns. While the chosen section size is among the smallest commercially-available cross-sections [45], members of similar crosssectional dimensions have been tested in previous studies [32,34,36,37] that have also examined larger sections, with similar conclusions having been drawn across the range of tested specimens. The cross-sectional geometry is shown in Figure 1, along with the positions of the steel reinforcing bars and the points of load application. For the eccentrically-loaded specimens, plates offset from the centreline of the tubes were welded onto the ends of the specimens, as shown in Figure 2. For the concentricallyloaded specimens, where end-plates were not required due to the absence of end moments, the column ends were held in position by means of wooden blocks. The nominal test parameters and associated ranges of variation are presented in Table 1 . The full schedule of test specimens is presented in Table 2.

The stub column length $L$ of $300 \mathrm{~mm}$ was chosen to be twice the major axis outer diameter $2 a$. This ensured that the stub columns were sufficiently short not to fail by overall buckling, yet still long enough to contain representative distributions of residual stresses and geometric imperfections.

Measurements of major and minor outer diameters ( $2 a$ and $2 b$, respectively), buckling length $L$ including the thicknesses of two $77 \mathrm{~mm}$ knife-edges, tube wall thickness $t$ and initial global imperfection in the axis of buckling $\omega_{\mathrm{g}}$ were taken for each slender column and are presented in Table 2, along with values of the reinforcement ratio $\rho$, equal to the ratio of the cross-sectional area of the steel reinforcement to that of the concrete core, load eccentricities $e_{y}$ and $e_{z}$ to the major and minor axes, respectively, nondimensional slenderness $\bar{\lambda}$ and the compressive strength of concrete $f_{\mathrm{c}}$ on the day of testing. For the concentrically-loaded specimens, which had measured global imperfections close to 
zero, a load eccentricity of $L / 1000$ was applied in the tests. The slender steel tubes were identified using the format of specimen number: nominal length in $\mathrm{m}$ - buckling axis load eccentricity in mm. For example, specimen E7:L3-MA-150 was $3 \mathrm{~m}$ in length and loaded with an eccentricity of $150 \mathrm{~mm}$ to the major axis. The identification labels of specimens containing steel reinforcement were suffixed with an 'R', e.g., specimen E21:L1-MA-50-R.

Holes of $50 \mathrm{~mm}$ diameter were cut into the top end-plates of the test specimens to allow access for the concrete to be poured in, as shown in Figure 3. The high workability of SCC was necessary for the concrete to flow through such an aperture. Owing to concrete shrinkage during curing, a small gap developed between the level of the hardened concrete and the top surface of the steel plate. This gap was backfilled with plaster of Paris to ensure a flat loading surface between the test rig and the columns.

\subsection{Material testing}

\subsubsection{Steel tubes}

EHS tubes of grade S355 steel and $150 \times 75 \times 6.3$ cross-section were used in the experimental programme. Tensile testing was conducted on coupons $300 \mathrm{~mm}$ in length that were cut from the EHS tubes. The testing was conducted in accordance with ISO 6892 Part 1 [46] using an Instron $750 \mathrm{kN}$ loading rig under displacement control at an initial strain rate of $1.4 \times 10^{-4} \mathrm{~s}^{-1}$. The strain rate was increased to $7.1 \times 10^{-4} \mathrm{~s}^{-1}$ in the strain hardening range in accordance with [46]. The material properties obtained from the tests are summarised in Table 3 while a typical stress-strain curve is shown in Figure 4. 


\subsubsection{Steel reinforcement}

For the seven specimens with steel reinforcement, four bars of T10 deformed steel reinforcement were positioned at the locations shown in Figure 1. This equates to a reinforcement ratio $\rho$ of $4.7 \%$. The material properties of the steel reinforcement measured from tensile testing, following the same procedures as described above, are presented in Table 3 while a typical stress-strain curve is presented in Figure 4.

\subsubsection{Concrete}

The concrete used to fill the elliptical tubes was designed to be class $C 30 / 37$, i.e. with a minimum compressive strength $f_{\mathrm{c}}$ of $30 \mathrm{MPa}$. Test cylinders were cast from every concrete mix and tested in compression on the day of the respective full-scale member experiments. Average concrete cylinder strength values for each test specimen are presented in Table 2. Aside from the target strength class, the suitability of an SCC mix is assessed primarily on the basis of two properties of the fresh concrete: workability and segregation resistance. Slump flow tests were performed on all concrete mixes in accordance with Annex B.1 of the EFNARC guidelines [47]. Where required, Conplast SP430 superplasticiser was added to the mix in order to achieve the required workability. Segregation resistance tests were performed on all batches of concrete with a segregation sieve in accordance with Annex B.4 of the EFNARC guidelines [47]. Pulverised fuel ash was added to the cement as a binder in order to aid segregation resistance [48]. A high level of segregation resistance is particularly important in vertical concrete applications to ensure that larger or heavier aggregates remain evenly distributed throughout the specimen, rather than settling and concentrating near the bottom of the tube. As can be seen in Figures 5 and 6, the aggregates were distributed evenly throughout the concrete with little to no air entrainment or bubbles, indicating both adequate workability and segregation resistance. To ensure sufficient clearance 
between the steel tube and the steel reinforcement, a maximum coarse aggregate size of $10 \mathrm{~mm}$ was specified for all mixes. It can be seen in Figure 6 that limiting the aggregate to this size enabled the concrete to pass around the reinforcing bars fully. The basic concrete mix that satisfied the strength, workability and segregation resistance criteria is detailed in Table 4. Owing to variations in the condition of the aggregates over the course of the experimental programme, it was necessary to modify the water content and superplasticiser content in some mixes to maintain the desired fresh concrete properties.

\subsection{Testing methods for CFEHS members}

The apparatus used to test the 24 slender CFEHS columns, which is shown in Figure 2, comprised an Instron $2000 \mathrm{kN}$ loading rig, hardened steel knife-edges each of $77 \mathrm{~mm}$ thickness with a maximum rotation of $15^{\circ}$ to provide pin-ended conditions in the intended axis of buckling and fixed conditions in the other cross-sectional axis, draw wire transducers at mid-height to measure deflections, inclinometers attached to the end-plates to measure end rotations, four linear electrical resistance strain gauges at the mid-height of the columns, DATASCAN data acquisition equipment and DSLOG data recording software. After securing the column in the rig, fixing the end-plates (or wooden blocks for the concentrically-loaded specimens) and attaching the measuring equipment, the hydraulic loading machine was set to displacement control at a rate of $0.1 \mathrm{~mm} / \mathrm{min}, 0.2 \mathrm{~mm} / \mathrm{min}$ or $0.3 \mathrm{~mm} / \mathrm{min}$ for columns of $1 \mathrm{~m}, 2 \mathrm{~m}$ or $3 \mathrm{~m}$ length, respectively. The test specimens were then loaded using the hydraulic jacks. Testing continued beyond the attainment of ultimate load and was stopped when the column had 
undergone at least $50 \mathrm{~mm}$ of lateral deflection at mid-height, thus enabling a considerable portion of the unloading behaviour of the specimens to be captured.

The tests on the three stub columns were carried out in an Instron $3500 \mathrm{kN}$ hydraulic testing machine, which is shown in Figure 7. The end-plattens of the testing apparatus were fixed flat and parallel. Four linear variable displacement transducers (LVDTs) were used to determine the end shortening of the stub columns between the end-plattens of the testing machine. Four linear electrical resistance strain gauges were attached to each specimen at mid-height. Readings of load, strain, axial displacement and input voltage were all recorded at a rate of $1 \mathrm{~Hz}$ using the DATASCAN data acquisition equipment and logged using the DSLOG computer package. The loading machine was set to displacement control at a rate of $0.17 \mathrm{~mm} / \mathrm{min}$ and the specimens were loaded in compression beyond the ultimate load until at least $20 \mathrm{~mm}$ of axial displacement was recorded.

\section{Experimental results}

In this section, the results of the experimental programme are presented, including the ultimate loads, second-order inelastic moments, load-displacement curves, strength indices and ductility indices.

\subsection{Failure modes and ultimate loads}


The slender columns all failed by global flexural buckling, as demonstrated by specimen E4:L3-MA-50 in Figure 8. For the stub columns, local buckling of the tube walls was observed. Shear bands were also seen to develop along the height of the concrete-filled stub columns, as shown in Figure 9. The ultimate loads obtained from the experiments $N_{\mathrm{u} \text { exp }}$ are presented in Table 5, along with the second-order inelastic ultimate moments $M_{\mathrm{u} \text { exp }}$, determined as:

$$
M_{\mathrm{u}, \exp }=N_{\mathrm{u}, \exp }\left(e+\omega_{\mathrm{g}}+\omega_{\mathrm{u}}\right)
$$

where $e$ is the initial load eccentricity to the axis of buckling, $\omega_{\mathrm{g}}$ is the initial global imperfection in the direction of buckling, taken either as the measured value or as $L / 1000$ in the case of a measured value of zero, and $\omega_{\mathrm{u}}$ is the mid-height lateral deflection at ultimate load.

\subsection{Load-deformation behaviour}

The general load-deformation behaviour of the columns can be characterised by graphs of load against lateral deflection at mid-height and graphs of load against axial displacement. Curves of load against lateral deflection at mid-height for the test members buckling about the major axis and minor axis are shown in Figures 10 and 11, respectively, while curves of load against axial displacement for the test members buckling about the major axis and minor axis are shown in Figures 12 and 13, respectively. In Figure 13, there are no data available for the axial displacement of specimen E17:L2-MI-50 owing to a fault in the recording equipment. Overall, the anticipated trend of decreasing ultimate load with increasing slenderness and increasing 
load eccentricity may be clearly observed. Curves of load against lateral deflection at mid-height for columns with steel reinforcement buckling about the major axis and minor axis are shown in Figures 14 and 15, respectively, while curves of load against axial displacement for columns with steel reinforcement buckling about the major axis and minor axis are shown in Figures 16 and 17, respectively. It may be observed that the greatest increase in strength for the specimens with steel reinforcement compared to those without steel reinforcement occurred for the members buckling about the major axis, due to the greater lever arm between the reinforcing bars and the cross-section centroidal axis - see Figure 1. The load-axial displacement curves for the three stub columns are shown in Figure 18, where, due to the very low slenderness of the stub columns, the response of the cross-sections in pure compression is isolated.

\subsection{Strength index}

The utilisation of the full plastic compressive resistance of a particular CFEHS column can be assessed through its strength index, SI, defined as:

$$
\mathrm{SI}=\frac{N_{\mathrm{u}, \mathrm{exp}}}{N_{\mathrm{pl}, \mathrm{Rd}}}
$$

where $N_{\mathrm{pl}, \mathrm{Rd}}$ is the plastic compressive resistance of the column cross-section, which is defined in EN 1994-1-1 [44] as:

$$
N_{\mathrm{pl}, \mathrm{Rd}}=A_{\mathrm{a}} f_{\mathrm{y}}+A_{\mathrm{c}} f_{\mathrm{c}}+A_{\mathrm{s}} f_{\mathrm{s}}
$$

where $A_{\mathrm{a}}, A_{\mathrm{c}}$ and $A_{\mathrm{s}}$ are the cross-sectional areas of the steel, concrete and steel reinforcement, respectively, and $f_{\mathrm{y}}, f_{\mathrm{c}}$ and $f_{\mathrm{s}}$ are the strengths of steel tube, concrete and steel reinforcement, respectively. Values of SI, based on measured geometric and 
material properties and with all partial factors set equal to unity, for the columns are presented in Table 5. Values of SI are plotted against slenderness for columns without reinforcement in Figure 19, while comparison between columns with and without steel reinforcement is made in Figure 20. Generally, as expected, it is observed that stockier columns with lower load eccentricities utilise considerably more of their plastic compressive resistance. It is further observed that the reinforced sections tend to have lower strength indices, which suggests that the relative strength increase expected from the inclusion of steel reinforcement, which affects the value of $N_{\mathrm{pl}, \mathrm{Rd}}$, is overestimated by the provisions of EN 1994-1-1 [44] for these specimens.

\subsection{Ductility index}

The ductility of a column can be quantified through its ductility index DI, defined as:

$$
\mathrm{DI}=\frac{\Delta_{\mathrm{u}}}{\Delta_{85 \%}}
$$

where $\Delta_{\mathrm{u}}$ is the axial displacement at ultimate load and $\Delta_{85 \%}$ is the axial displacement when the load reduces to $85 \%$ of the ultimate load on the unloading branch [36]. For specimens with a low DI, the load drops away quickly after the peak load has been reached, while for specimens with a high DI, the columns are capable of maintaining loads closer to the ultimate load with larger accompanying displacements. Values of DI obtained from the tests are presented in Table 5. Values of DI are not available for stub column specimens E26 and E27 due to the tests having not been continued for sufficient deformation for the load to drop to $85 \%$ of the ultimate load. Values of DI for specimens without reinforcement are plotted against slenderness in Figure 21, while 
comparison is made in Figure 22 for the DI of specimens with and without steel reinforcement. Overall, it may be observed that there is a general reduction in ductility with increasing slenderness and that the presence of steel reinforcement does not have a large influence on the ductility of the studied columns.

\section{Comparison with provisions of EN 1994-1-1}

In this section, the ultimate loads obtained from the experimental programme are compared with predicted resistances based on the design provisions for CFST columns given in EN 1994-1-1 [44]. At present, there are no specific provisions for elliptical section members in the European Standards, so comparison is made with the provisions for CFST columns with circular and rectangular cross-sections.

\subsection{Resistance of members in axial compression}

For columns in axial compression, it is stated in EN 1994-1-1 [44] that the nondimensional slenderness $\bar{\lambda}$ for a composite section is to be used to calculate a buckling reduction factor $\chi$ using the buckling curves provided in EN 1993-1-1 [49]. This reduction factor is multiplied by the plastic resistance of the cross-section in compression $N_{\mathrm{pl}, \mathrm{Rd}}$ to provide the predicted design resistance $N_{\mathrm{u}, \mathrm{EC} 4}$ of the concentrically-loaded column. The nondimensional slenderness $\bar{\lambda}$ is defined as: 


$$
\bar{\lambda}=\sqrt{\frac{N_{\mathrm{pl}, \mathrm{Rd}}}{N_{\mathrm{cr}}}} .
$$

where $N_{\mathrm{pl}, \mathrm{Rd}}$ is defined in Equation 3, and the elastic critical buckling load $N_{\mathrm{cr}}$ for a composite member is given by:

$$
N_{\mathrm{cr}}=\frac{\pi^{2}(E I)_{\mathrm{eff}}}{L^{2}}
$$

where the effective flexural stiffness of the composite cross-section $(E I)_{\mathrm{eff}}$ is defined in EN 1994-1-1 [44] as:

$$
(E I)_{\mathrm{eff}}=E_{\mathrm{a}} I_{\mathrm{a}}+0.6 E_{\mathrm{cm}} I_{\mathrm{c}}+E_{\mathrm{s}} I_{\mathrm{s}}
$$

in which $E_{\mathrm{a}}$, and $E_{\mathrm{s}}$ are the moduli of elasticity of the steel tube and steel reinforcement, respectively, the secant modulus of concrete $E_{\mathrm{cm}}$ is taken as $32000 \mathrm{MPa}$ for C30 concrete [1], and $I_{\mathrm{a}}, I_{\mathrm{c}}$ and $I_{\mathrm{s}}$ are the second moments of area of the steel section, concrete section and the reinforcement, respectively, about the buckling axis in question.

\subsection{Resistance of members in combined compression and uniaxial bending}

For eccentrically-loaded columns, the effects of combined compression and uniaxial bending must be accounted for. The first-order design moment $M_{\mathrm{Ed}}$ arising from the effects of the eccentric application of the axial load $N_{\mathrm{Ed}}$ and the initial global imperfection is:

$$
M_{\mathrm{Ed}}=N_{\mathrm{Ed}}\left(e+\omega_{\mathrm{g}}\right)
$$

The amplitude of the initial imperfection $\omega_{\mathrm{g}}$ for CHS and RHS members according to EN 1994-1-1 [44] is $L / 300$ for members with a reinforcement ratio $\rho \leq 3 \%$ and $L / 200$ 
for $3 \%<\rho \leq 6 \%$. Second-order effects arising from the lateral deflection of the column are accounted for by amplifying $M_{\mathrm{Ed}}$ by a factor $k$, defined as:

$$
k=\frac{\beta}{1-N_{\mathrm{Ed}} / N_{\mathrm{cr}, \mathrm{eff}}} .
$$

where $\beta$ is an equivalent moment factor set to 1.1 for equal and opposite end moment loading and $N_{\text {cr,eff }}$ is the elastic critical buckling load calculated using the effective flexural stiffness $(E I)_{\mathrm{eff}, \mathrm{II}}$, defined as:

$$
(E I)_{\mathrm{eff}, I \mathrm{I}}=0.9\left(E_{\mathrm{a}} I_{\mathrm{a}}+0.5 E_{\mathrm{cm}} I_{\mathrm{c}}+E_{\mathrm{s}} I_{\mathrm{s}}\right) .
$$

Thus, the curve relating the axial load to the second-order moment is defined. The resistance of the composite column is defined using moment-axial load interaction curves. In the present study, these curves were derived using numerical integration to determine the level of bending moment that could be sustained for a given axial load, assuming a fully plastic distribution of stresses and that the concrete did not act in tension. According to EN 1994-1-1 [44], for grades S275 and S355 steel, the following inequality must be satisfied:

$$
\frac{M_{\mathrm{Ed}}}{M_{\mathrm{pl}, N, \mathrm{Rd}}} \leq 0.9
$$

where $M_{\mathrm{pl}, N, \mathrm{Rd}}$ is the plastic moment resistance of the composite column accounting for the presence of the axial load. For grades S420 and S460, the coefficient 0.9 is replaced by 0.8 . The predicted design resistance $N_{\mathrm{u}, \mathrm{EC} 4}$ for the eccentrically-loaded column is given by the intersection of the loading and resistance curves, as shown in Figure 23.

\subsection{Comparison with experimental results}


It can be seen in Table 6 and Figure 24 that the design resistances predicted by EN 1994-1-1 [44] are generally conservative when compared with the experimental results, indicating that the rules intended for use with concrete-filled CHS and RHS columns are also safe to use in the design of CFEHS columns buckling about either the major axis or minor axis and either with or without steel reinforcement. 


\section{Conclusions}

The results of an experimental programme comprising tests on 27 concrete-filled steel elliptical hollow section members have been presented. The test specimens included 3 stub columns and 24 slender columns, 6 of which were loaded concentrically with the remainder loaded eccentrically about either the major axis or the minor axis. Seven of the specimens also contained steel reinforcement.

The experimental results for the ultimate load of the columns followed expected trends of reduced capacity with increased slenderness and load eccentricity. As was also found by [37] for columns buckling about the minor axis, there was little additional loadcarrying capacity associated with the inclusion of steel reinforcement. For the test specimens buckling about the major axis, the inclusion of steel reinforcement led to a marked increase in the ultimate load, due to the greater lever arm between the reinforcing bars.

Values of strength index (SI) and ductility index (DI) were also calculated for the test specimens. It was found that, while the test results followed expected trends of reducing SI with increasing slenderness and load eccentricity, the inclusion of steel reinforcement led to a slight decrease in the SI. This may be because the relative increase in strength predicted by EN 1994-1-1 [44] is in fact overestimated when compared to the experimental results. Analysis of the test results for DI showed that for members buckling about the major axis, the DI increased with load eccentricity. This trend was not as clearly observed for the specimens buckling about the minor axis. For the 
specimens with steel reinforcement, there appeared to be no significant change in DI when compared to the specimens without reinforcement.

The test results were compared with the provisions of EN 1994-1-1 [44] for concretefilled CHS and RHS columns. Overall, the comparisons indicated that the current provisions for the design of concrete-filled CHS and RHS columns are also suitable for the design of CFEHS columns.

\section{Acknowledgements}

The authors would like to express their sincere gratitude to the European Union for the help provided through Project RFSR-CT-2012-00025, carried out with a financial grant from the Research Programme of the Research Fund for Coal and Steel.

The authors would also like to thank Maria Fligkou for her considerable input into the research, as well as the technical staff of the Structures Laboratory at the Department of Civil and Environmental Engineering at Imperial College London, in particular Stefan Algar, Gordon Herbert and Leslie Clark, for their expertise, guidance and assistance in conducting this research. 


\section{References}

[1] Bergmann, R., Matsui, C., Meinsma, C., Dutta, D. 1995. Design Guide for Concrete Filled Hollow Section Columns under Static and Seismic Loading, CIDECT Design Guide 5. CIDECT.

[2] Espinos, A., Gardner, L., Romero, M., Hospitaler, A. 2011. Fire behaviour of concrete filled elliptical steel columns. Thin-Walled Structures, 49(2), 239-255.

[3] Shanmugam, N. E., Lakshmi, B. 2001. State of the art report on steel-concrete composite columns. J. Const. Steel Res., 57, 1041-1080.

[4] Neogi, P.K., Sen, H. K., Chapman, J. C. 1969. Concrete-filled tubular steel columns under eccentric loading. The Struct. Eng., 47(5), 187-95.

[5] Knowles R.B., Park R. 1969. Strength of concrete filled steel tubular columns. $J$. Struct. Div., ASCE, 105(12), 2565-87.

[6] Drysdale, R.G., Huggins, M.W. 1971. Sustained biaxial load on slender concrete columns. J. Struct. Eng., ASCE, 97(5), 1423-42.

[7] Yang. H., Lam, D., Gardner, L. (2008). Testing and analysis of concrete-filled elliptical hollow sections. Eng. Struct., 30, 3771-3781.

[8] Mander, J. B., Priestly, M. J. N., Park, R. 1988. Theoretical stress-strain model for confined concrete. J. Struct. Eng., ASCE, 114(8), 1804-1825.

[9] Lie, T. T. 1994. Fire resistance of circular steel columns filled with bar-reinforced concrete. J. Struct. Eng., ASCE, 120(5), 1489-1509.

[10] Lie, T. T., Irwin, R. J. 1995. Fire resistance of rectangular steel columns filled with bar reinforced concrete. J. Struct. Eng., ASCE, 121(5), 797-805.

[11] Yang, Y.-F., Han, L.-H., 2011. Behaviour of concrete filled steel tubular (CFST) stub columns under eccentric partial compression, Thin-Walled Struct., 49, 379395.

[12] Han, L.-H. 2002. Tests on stub columns of concrete-filled RHS sections. J. Const. Steel. Res., 58, 353-372.

[13] Han, L.-H, Yao, G. H, Zhao, X. 2005. Tests and calculations for hollow structural steel (HSS) stub columns filled with self-consolidating concrete (SCC). J. Const. Steel. Res., 61(9), 1241-1269.

[14] Tao, Z., Han, L.-H., Wang, Z.-B. 2005. Experimental behavior of stiffened concrete-filled thin-walled hollow steel structural (HSS) stub columns. J. Const. Steel Res., 61, 962-983. 
[15] Mursi, M., Uy, B. 2004. Strength of slender concrete filled high strength steel box columns. J. Const. Steel Res., 60, 1825-1848.

[16] Zeghiche, J., Chaoui, K. 2005. An experimental behaviour of concrete-filled steel tubular columns. J. Const. Steel Res, 61(1), 53-66.

[17] Portoles, J. M., Romero, M. L., Bonet, J. L., Filippou, F. C. 2011. Experimental study of high strength concrete-filled circular tubular columns under eccentric loading. J. Const. Steel Res., 67, 623-633.

[18] Young, B., Ellobody, E. 2006. Experimental investigation of concrete-filled coldformed high strength stainless steel tube columns. J. Const. Steel Res., 62, 484492.

[19] Lam, D., Gardner, L. 2008. Structural design of stainless steel concrete filled columns. J. Const. Steel Res., 64, 1275-1282.

[20] Uy, B., Tao, Z., Han, L.-H. 2011. Behaviour of short and slender concrete-filled stainless steel tubular columns. J. Const. Steel Res., 67, 360-378.

[21] Han, L.-H., Li, W., Bjorhovde, R. 2014. Developments and advanced applications of concrete-filled steel tubular (CFST) structures: Members, J. Const. Steel Res., 100, 211-228.

[22] Comité Européen de Normalisation. 2006. EN 10210-1:2006 Hot finished structural hollow sections of non-alloy and fine grain steels - Part 1: Technical delivery conditions. British Standards Institution.

[23] Ruiz-Teran, A. M., Gardner, L. 2008. Elastic buckling of elliptical tubes. ThinWalled Struct., 46, 1304-1318.

[24] Chan, T. M., Gardner, L. 2008. Compressive resistance of hot-rolled elliptical hollow sections. Eng. Struct., 30, 522-532.

[25] Law, K.H., Gardner, L. 2013. Buckling of elliptical hollow section members under combined compression and uniaxial bending. J. Const. Steel Res., 86, 1-16.

[26] Chan. T. M., Gardner, L. 2008. Bending strength of hot-rolled elliptical hollow sections. J. Const. Steel Res., 64, 971-986.

[27] Chan, T. M., Gardner L. 2009. Flexural buckling of elliptical hollow section columns. J. Struct. Eng., ASCE, 135(5), 546-557.

[28] Law, K. H., Gardner, L. 2012. Lateral instability of elliptical hollow section beams. Eng. Struct,, 37, 152-166.

[29] Silvestre, N., Gardner, L. 2011. Elastic post-buckling of elliptical tubes. J. Const. Steel Res., 67, 281-292. 
[30] Chan T.M., Gardner L., Law K.H. 2010. Structural design of elliptical hollow sections: a review. Proc. Inst. Civil Engrs Struct. Build., 163(6), 391-402

[31] Gardner, L., Chan, T. M., Wadee, M.A. 2008. Shear response of elliptical hollow sections. Proc. Inst. Civil Engrs Struct. Build. 161(6), 301-309.

[32] Zhao, X.-L., Packer, J. A. 2009. Tests and design of concrete-filled elliptical hollow section stub columns. Thin-Walled Struct., 47, 617-628.

[33] Uenaka, K. 2014. Experimental study on concrete filled elliptical/oval steel tubular stub columns under compression. Thin-Walled Struct., 78, 131-137.

[34] Jamaluddin, N., Lam, D., Dai, X. H.,Ye. J. 2013. An experimental study on elliptical concrete filled columns under axial compression. J. Const. Steel Res., 87 6-16.

[35] Sheehan, T, Dai, X. H., Chan, T. M., Lam, D. 2012. Structural response of concrete-filled elliptical steel hollow sections under eccentric compression. Eng. Struct. 45, 314-323.

[36] Ren, Q.-X., Han, L.-H., Lam, D., Li, W. 2014. Tests on elliptical concrete filled steel tubular (CFST) beams and columns. J. Const. Steel Res., 99, 149-160.

[37] Espinos, A., Romero, M. L., Portolés, J, M., Hospitaler, A. 2014. Ambient and fire behavior of eccentrically loaded elliptical slender concrete-filled tubular columns. J. Const. Steel Res., 100, 97-107.

[38] Domone, P. L. 2006. Self-compacting concrete: An analysis of 11 years of case studies. Cement \& Conc. Composites, 28, 197-208.

[39] Okamura, H., Ouchi, M. (2003). Self-compacting concrete. J. Adv. Conc. Tech. 1(1), $5-15$.

[40] Persson, B. 2001. A comparison between mechanical properties of self-compacting concrete and the corresponding properties of normal concrete. Cement \& Conc. Res., 31(2), 193--198.

[41] Zhu, W., Bartos, P. 2003. Permeation properties of self-compacting concrete. Cement \& Conc. Res., 33(6), 921--926.

[42] Han, L.-H., Lu, H., Yao, G.-H., Liao, F.-Y. 2006. Further study on the flexural behaviour of concrete-filled steel tubes. J. Const. Steel Res., 62, 554-565.

[43] Muciaccia, G., Giussani, F., Rosati, G., Mola, F. Response of self-compacting concrete filled tubes under eccentric compression. J. Const. Steel Res., 67, 904916. 
[44] Comité Européen de Normalisation. 2004. EN 1994-1-1:2004 Eurocode 4: Design of composite steel and concrete structures - Part 1-1: General rules and rules for buildings. British Standards Institute.

[45] Tata Steel. 2011. Celsius ${ }^{\circledR} 355$ technical guide - structural hollow sections. Tata Steel Europe.

[46] British Standards Institution. 2009. Metallic materials - tensile testing Part 1: Method of test at ambient temperature (BS EN ISO 6892-1: 2009), British Standards Institution.

[47] European Federation of Specialist Construction Chemicals and Concrete Systems. 2005. European Guidelines for Self Compacting Concrete - Specification, Production and Use. EFNARC.

[48] Liu, M. 2010. Self-compacting concrete with different levels of pulverized fuel ash. Const. \& Build. Mat. 24, 1245-1252.

[49] Comité Européen de Normalisation. 2005. EN 1993-1-1:2005 Eurocode 3: Design of steel structures - Part 1-1: General rules and rules for buildings. British Standards Institute. 
Table 1

\begin{tabular}{cc}
\hline Parameter & Range \\
\hline$L$ & $1 \mathrm{~m}, 2 \mathrm{~m}, 3 \mathrm{~m}, 300 \mathrm{~mm}$ (stubs) \\
Buckling axis & major, minor \\
$\bar{\lambda}$ & $0.3-1.7$ \\
$e$ & $0-2 a ; 0-1.33 b$ \\
$\rho$ & $0 \%, 5 \%$ \\
\hline
\end{tabular}


Table 2

\begin{tabular}{|c|c|c|c|c|c|c|c|c|c|c|c|}
\hline Specimen & $\begin{array}{c}L \\
(\mathrm{~mm} \\
)\end{array}$ & $\bar{\lambda}$ & $\begin{array}{c}2 a \\
(\mathrm{~mm})\end{array}$ & $\begin{array}{c}2 b \\
(\mathrm{~mm})\end{array}$ & $\begin{array}{c}t \\
(\mathrm{~mm})\end{array}$ & $\begin{array}{c}e_{y} \\
(\mathrm{~mm})\end{array}$ & $\begin{array}{c}e_{z} \\
(\mathrm{~mm})\end{array}$ & $\begin{array}{c}\rho \\
(\%)\end{array}$ & $\begin{array}{l}\text { Buckling } \\
\text { axis }\end{array}$ & $\begin{array}{c}f_{\mathrm{c}} \\
(\mathrm{MPa})\end{array}$ & $\begin{array}{c}\omega_{\mathrm{g}} \\
(\mathrm{mm})\end{array}$ \\
\hline E1:L3-MA-0 & 3154 & 1.00 & 148.21 & 75.77 & 6.30 & 0.0 & 0.0 & 0 & Major & 36.0 & 0.0 \\
\hline E2:L2-MA-0 & 2154 & 0.67 & 148.45 & 75.78 & 6.30 & 0.0 & 0.0 & 0 & Major & 32.0 & 0.0 \\
\hline E3:L1-MA-0 & 1154 & 0.36 & 148.37 & 75.63 & 6.30 & 0.0 & 0.0 & 0 & Major & 33.0 & 0.0 \\
\hline E4:L3-MA-50 & 3154 & 1.00 & 148.50 & 75.79 & 6.30 & 0.0 & 50.0 & 0 & Major & 36.5 & 0.8 \\
\hline E5:L2-MA-50 & 2154 & 0.68 & 148.96 & 76.04 & 6.30 & 0.0 & 50.0 & 0 & Major & 38.3 & 0.3 \\
\hline E6:L1-MA-50 & 1154 & 0.36 & 148.37 & 76.00 & 6.30 & 0.0 & 50.0 & 0 & Major & 28.7 & 0.0 \\
\hline E7:L3-MA-150 & 3154 & 1.00 & 150.75 & 75.93 & 6.30 & 0.0 & 150.0 & 0 & Major & 42.7 & 1.0 \\
\hline E8:L2-MA-150 & 2154 & 0.67 & 148.71 & 75.86 & 6.30 & 0.0 & 150.0 & 0 & Major & 33.2 & 0.0 \\
\hline E9:L1-MA-150 & 1154 & 0.36 & 148.52 & 75.87 & 6.30 & 0.0 & 150.0 & 0 & Major & 36.2 & 0.0 \\
\hline E10:L3-MI-0 & 3154 & 1.78 & 149.19 & 76.00 & 6.30 & 0.0 & 0.0 & 0 & Minor & 40.6 & 0.0 \\
\hline E11:L2-MI-0 & 2154 & 1.20 & 148.95 & 75.77 & 6.30 & 0.0 & 0.0 & 0 & Minor & 35.4 & 0.0 \\
\hline E12:L1-MI-0 & 1154 & 0.65 & 148.64 & 75.45 & 6.30 & 0.0 & 0.0 & 0 & Minor & 36.0 & 0.0 \\
\hline E13:L3-MI-25 & 3154 & 1.79 & 148.28 & 75.97 & 6.30 & 25.0 & 0.0 & 0 & Minor & 41.8 & 0.0 \\
\hline E14:L2-MI-25 & 2154 & 1.20 & 148.58 & 75.92 & 6.30 & 25.0 & 0.0 & 0 & Minor & 37.0 & 0.5 \\
\hline E15:L1-MI-25 & 1154 & 0.63 & 148.79 & 75.92 & 6.30 & 25.0 & 0.0 & 0 & Minor & 32.2 & 0.3 \\
\hline E16:L3-MI-50 & 3154 & 1.7 & 148.76 & 76.07 & 6.30 & 50.0 & 0.0 & 0 & Minor & 33.0 & 0.2 \\
\hline E17:L2-MI-50 & 2154 & 1.19 & 148.99 & 75.68 & 6.30 & 50.0 & 0.0 & 0 & Minor & 33.1 & 0.0 \\
\hline E18:L1-MI-50 & 1154 & 0.63 & 148.66 & 75.95 & 6.30 & 50.0 & 0.0 & 0 & Minor & 28.7 & 0.3 \\
\hline $\begin{array}{l}\text { E19:L3-MA-50- } \\
\text { R }\end{array}$ & 3154 & 0.93 & 149.45 & 75.66 & 6.30 & 0.0 & 50.0 & 4.7 & Major & 32.6 & 4.0 \\
\hline $\begin{array}{l}\text { E20:L2-MA-50- } \\
\text { R }\end{array}$ & 2154 & 0.65 & 148.19 & 75.66 & 6.30 & 0.0 & 50.0 & 4.7 & Major & 38.7 & 0.0 \\
\hline $\begin{array}{l}\text { E21:L1-MA-50- } \\
\text { R }\end{array}$ & 1154 & 0.35 & 148.50 & 75.99 & 6.30 & 0.0 & 50.0 & 4.7 & Major & 35.9 & 0.0 \\
\hline E22:L3-MI-25-R & 3154 & 1.72 & 149.41 & 75.93 & 6.30 & 25.0 & 0.0 & 4.7 & Minor & 31.8 & 1.5 \\
\hline E23:L2-MI-25-R & 2154 & 1.19 & 148.59 & 76.06 & 6.30 & 25.0 & 0.0 & 4.7 & Minor & 35.8 & 0.3 \\
\hline E24:L1-MI-25-R & 1154 & 0.64 & 149.75 & 75.45 & 6.30 & 25.0 & 0.0 & 4.7 & Minor & 36.1 & 0.0 \\
\hline E25:hollow & 300 & 0.15 & 149.33 & 75.59 & 6.52 & 0.0 & 0.0 & 0 & Stub & - & - \\
\hline E26:stub & 300 & 0.17 & 149.32 & 75.48 & 6.43 & 0.0 & 0.0 & 0 & Stub & 38.1 & - \\
\hline E27:stub-R & 300 & 0.18 & 149.57 & 75.71 & 6.42 & 0.0 & 0.0 & 4.7 & Stub & 38.1 & - \\
\hline
\end{tabular}

*Note that for the concentrically-loaded specimens, which had measured global imperfections close to zero, a load eccentricity of $L / 1000$ was applied in the tests. 
Table 3

\begin{tabular}{lcc}
\hline Material property & EHS tubes & Reinforcing bars \\
\hline Modulus of elasticity $E(\mathrm{MPa})$ & 205700 & 198300 \\
Yield strength $f_{\mathrm{y}}(\mathrm{MPa})$ & 369.1 & 561.7 \\
Ultimate strength $f_{\mathrm{u}}(\mathrm{MPa})$ & 495.0 & 667.7 \\
Ultimate strain $\varepsilon_{\mathrm{u}}(\%)$ & 18.4 & 13.2 \\
Strain at fracture $\varepsilon_{\mathrm{f}}(\%)$ & 37.0 & 18.5 \\
\hline
\end{tabular}

Table 4

\begin{tabular}{lc}
\hline Component & Content $\left(\mathrm{kg} / \mathrm{m}^{3}\right)$ \\
\hline Water & 180 \\
Cement & 420 \\
Pulverised fuel ash & 100 \\
$10 \mathrm{~mm}$ coarse aggregate & 800 \\
Fine aggregate & 950 \\
Superplasticiser & 4 \\
\hline
\end{tabular}


Table 5

\begin{tabular}{|c|c|c|c|c|}
\hline Specimen & $N_{\mathrm{u}, \exp }(\mathrm{kN})$ & $M_{\mathrm{u}}(\mathrm{kN} \mathrm{m})$ & SI & DI \\
\hline E1:L3-MA-0 & 761.5 & 17.4 & 0.73 & 1.12 \\
\hline E2:L2-MA-0 & 886.6 & 5.9 & 0.88 & 1.46 \\
\hline E3:L1-MA-0 & 1059.3 & 3.5 & 1.04 & 1.91 \\
\hline E4:L3-MA-50 & 348.5 & 34.8 & 0.33 & 1.56 \\
\hline E5:L2-MA-50 & 359.8 & 29.4 & 0.34 & 1.68 \\
\hline E6:L1-MA-50 & 508.6 & 33.5 & 0.51 & 2.05 \\
\hline E7:L3-MA-150 & 176.3 & 35.9 & 0.16 & 1.80 \\
\hline E8:L2-MA-150 & 199.2 & 36.0 & 0.20 & 2.43 \\
\hline E9:L1-MA-150 & 222.7 & 37.8 & 0.21 & 3.22 \\
\hline E10:L3-MI-0 & 349.0 & 12.7 & 0.32 & 1.72 \\
\hline E11:L2-MI-0 & 664.3 & 15.1 & 0.64 & 1.06 \\
\hline E12:L1-MI-0 & 831.3 & 3.9 & 0.80 & 1.40 \\
\hline E13:L3-MI-25 & 222.5 & 19.2 & 0.21 & 1.54 \\
\hline E14:L2-MI-25 & 337.9 & 19.6 & 0.32 & 1.76 \\
\hline E15:L1-MI-25 & 460.3 & 17.4 & 0.45 & 2.04 \\
\hline E16:L3-MI-50 & 167.9 & 10.1 & 0.16 & 1.51 \\
\hline E17:L2-MI-50 & 245.8 & 22.5 & 0.24 & 1.56 \\
\hline E18:L1-MI-50 & 321.6 & 21.8 & 0.32 & 1.83 \\
\hline E19:L3-MA-50-R & 370.2 & 39.1 & 0.31 & 1.48 \\
\hline E20:L2-MA-50-R & 482.3 & 41.2 & 0.40 & 1.60 \\
\hline E21:L1-MA-50-R & 578.6 & 36.4 & 0.48 & 2.51 \\
\hline E22:L3-MI-25-R & 225.7 & 20.5 & 0.19 & 1.69 \\
\hline E23:L2-MI-25-R & 353.3 & 20.7 & 0.29 & 1.77 \\
\hline E24:L1-MI-25-R & 492.7 & 19.6 & 0.41 & 1.77 \\
\hline E25:hollow & 1002.0 & - & 1.25 & 1.28 \\
\hline E26:stub & 1176.9 & - & 1.11 & - \\
\hline E27:stub-R & 1470.5 & - & 1.20 & - \\
\hline
\end{tabular}


Table 6

\begin{tabular}{lccc}
\hline Specimen & $N_{\mathrm{u}, \mathrm{EC} 4}(\mathrm{kN})$ & $N_{\mathrm{u}, \text { exp }}(\mathrm{kN})$ & $N_{\mathrm{u}, \text { exp }} / N_{\mathrm{u}, \mathrm{EC} 4}$ \\
\hline E1:L3-MA-0 & 691.4 & 761.5 & 1.10 \\
E2:L2-MA-0 & 870.4 & 886.6 & 1.02 \\
E3:L1-MA-0 & 978.8 & 1059.3 & 1.08 \\
E4:L3-MA-50 & 301.3 & 348.5 & 1.16 \\
E5:L2-MA-50 & 376.1 & 359.8 & 0.96 \\
E6:L1-MA-50 & 413.8 & 508.6 & 1.23 \\
E7:L3-MA-150 & 153.7 & 176.3 & 1.15 \\
E8:L2-MA-150 & 163.0 & 199.2 & 1.22 \\
E9:L1-MA-150 & 177.3 & 222.7 & 1.26 \\
E10:L3-MI-0 & 296.9 & 349.0 & 1.18 \\
E11:L2-MI-0 & 550.9 & 664.3 & 1.21 \\
E12:L1-MI-0 & 904.3 & 831.3 & 0.92 \\
E13:L3-MI-25 & 184.1 & 222.5 & 1.21 \\
E14:L2-MI-25 & 283.2 & 337.9 & 1.19 \\
E15:L1-MI-25 & 404.2 & 460.3 & 1.14 \\
E16:L3-MI-50 & 145.5 & 167.9 & 1.15 \\
E17:L2-MI-50 & 200.0 & 245.8 & 1.23 \\
E18:L1-MI-50 & 260.8 & 321.6 & 1.23 \\
E19:L3-MA-50-R & 344.4 & 370.2 & 1.07 \\
E20:L2-MA-50-R & 420.3 & 482.3 & 1.15 \\
E21:L1-MA-50-R & 486.1 & 578.6 & 1.19 \\
E22:L3-MI-25-R & 199.5 & 225.7 & 1.13 \\
E23:L2-MI-25-R & 303.3 & 353.3 & 1.17 \\
E24:L1-MI-25-R & 514.0 & 492.7 & 0.96 \\
E25:hollow & 799.0 & 1002.0 & 1.25 \\
E26:stub & 1056.1 & 1176.9 & 1.11 \\
E27:stub-R & 1223.8 & 1470.5 & 1.20 \\
\hline Average & & & 1.14 \\
Standard deviation & & & 0.09 \\
\hline & & & \\
& & & \\
\hline
\end{tabular}


Figure 1 Cross-sectional geometry of CFEHS specimens with reinforcement and eccentric load positions

Figure 2 Layout of loading rig for tests on slender columns (left: eccentric load tests; right: concentric load tests)

Figure 3 Concrete-filled specimen with access hole indicated, prior to backfilling with plaster of Paris

Figure 4 Stress-strain curves obtained from tensile testing of steel materials

Figure 5 Section of column after testing showing even distribution of aggregates throughout column length, indicating adequate segregation resistance of SCC

Figure 6 Cross-section of a specimen with steel reinforcing bars highlighted, demonstrating the ability of the concrete to fill around the bars

Figure 7 Test rig used for stub column tests

Figure 8 Flexural buckling of specimen E4:L3-MA-50

Figure 9 Shear bands evident in reinforced stub column E27:stub-R after testing

Figure 10 Load-lateral deflection at mid-height curves for columns buckling about the major axis

Figure 11 Load-lateral deflection at mid-height curves for columns buckling about the minor axis

Figure 12 Load-axial displacement curves for columns buckling about the major axis

Figure 13 Load-axial displacement curves for columns buckling about the minor axis

Figure 14 Comparison of graphs of load against lateral deflection at mid-height for columns with and without steel reinforcement buckling about the major axis

Figure 15 Comparison of graphs of load against lateral deflection at mid-height for columns with and without steel reinforcement buckling about the minor axis

Figure 16 Comparison of load-axial displacement curves for columns with and without steel reinforcement buckling about the major axis

Figure 17 Comparison of load-axial displacement curves for columns with and without steel reinforcement buckling about the minor axis

Figure 18 Comparison of load-axial displacement curves for stub columns

Figure 19 Comparison of strength indices for test specimens without steel reinforcement

Figure 20 Comparison of strength indices for test specimens with and without reinforcement

Figure 21 Comparison of ductility indices for test specimens without reinforcement

Figure 22 Comparison of ductility indices for test specimens with and without reinforcement 
Figure 23 Example of moment-load interaction curves for specimen E4:L3-MA-50, which are used to determine design resistance for members in combined compression and uniaxial bending

Figure 24 Comparison of experimental ultimate loads with predicted design resistances 


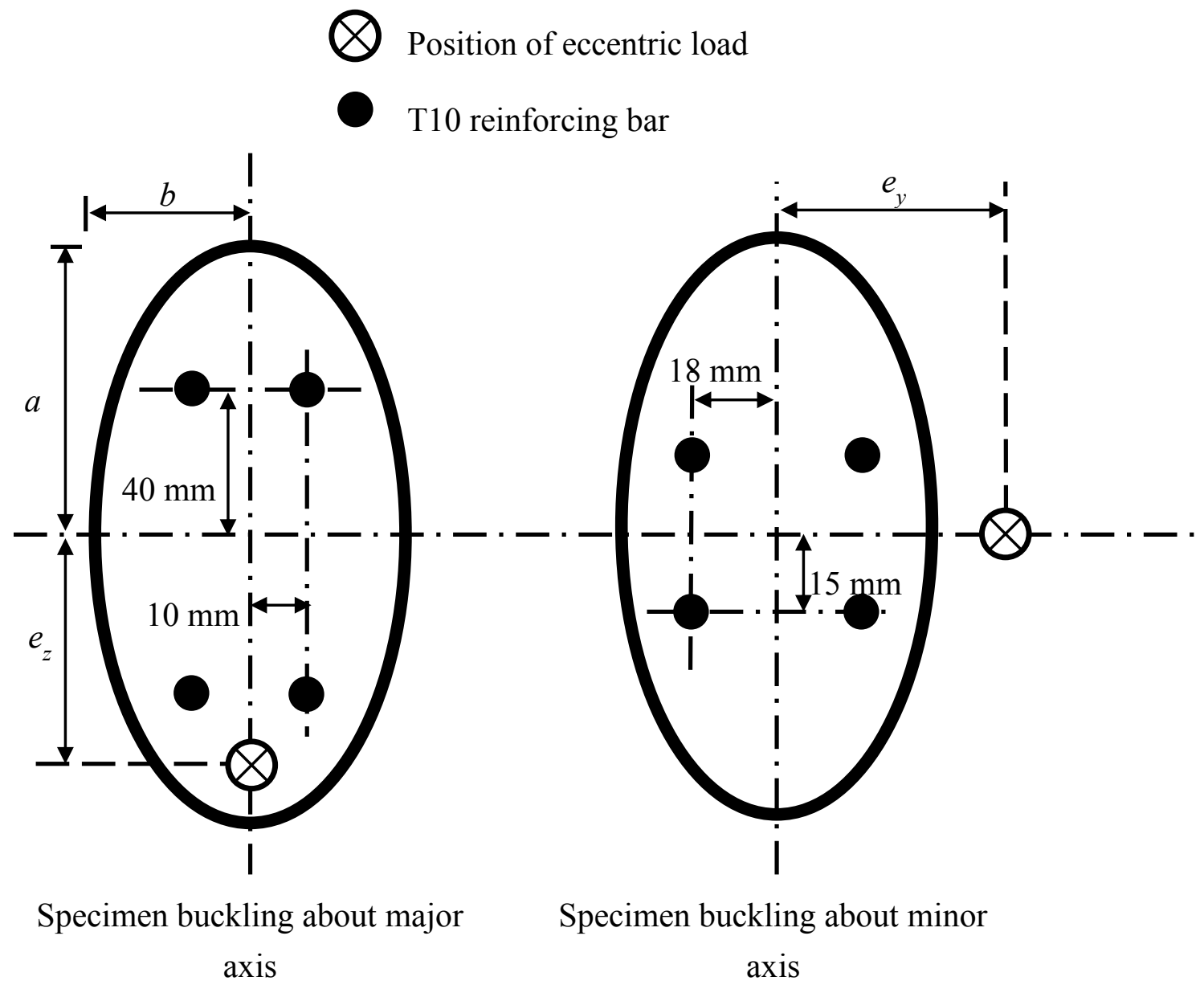

Figure 25 


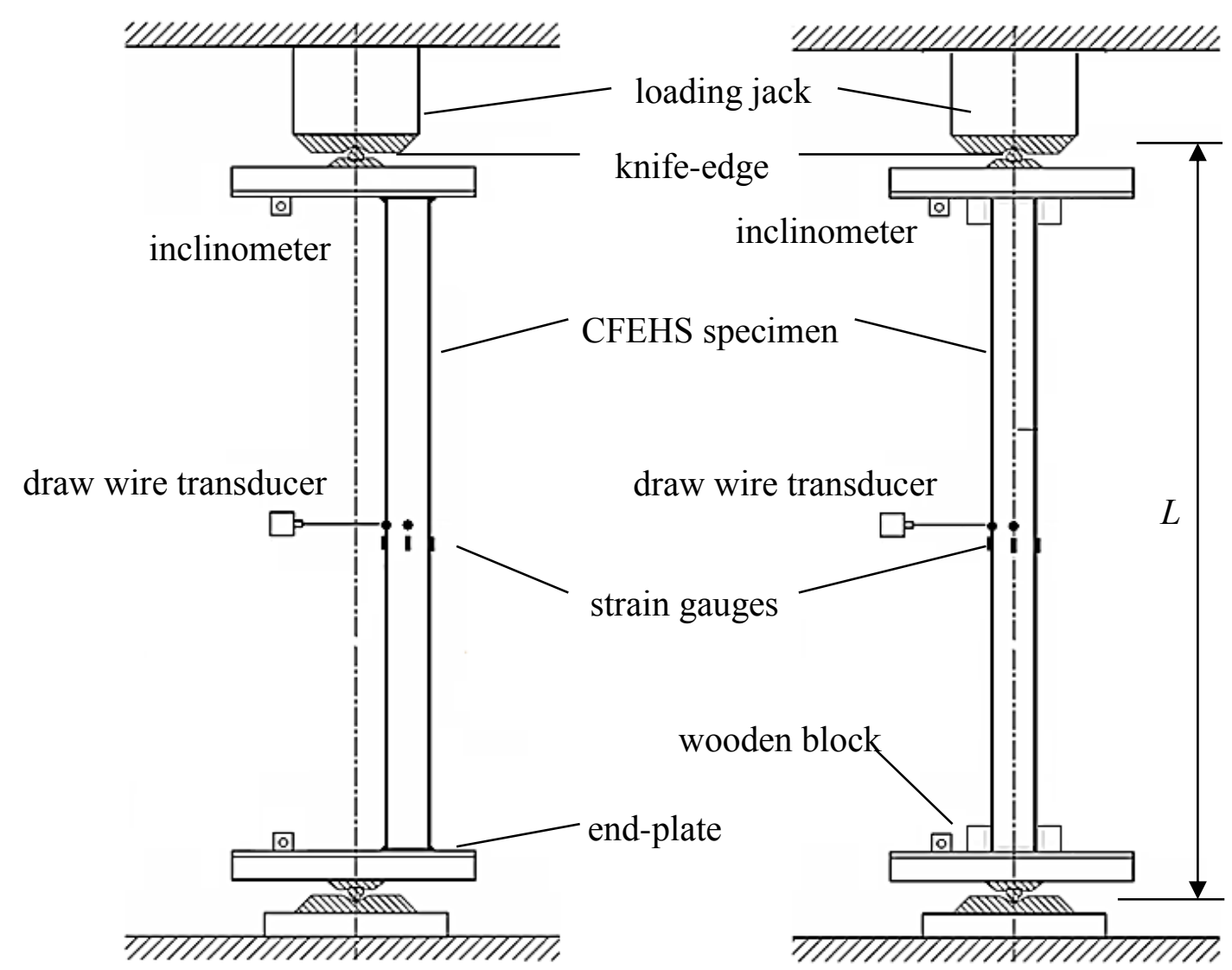

Figure 26 


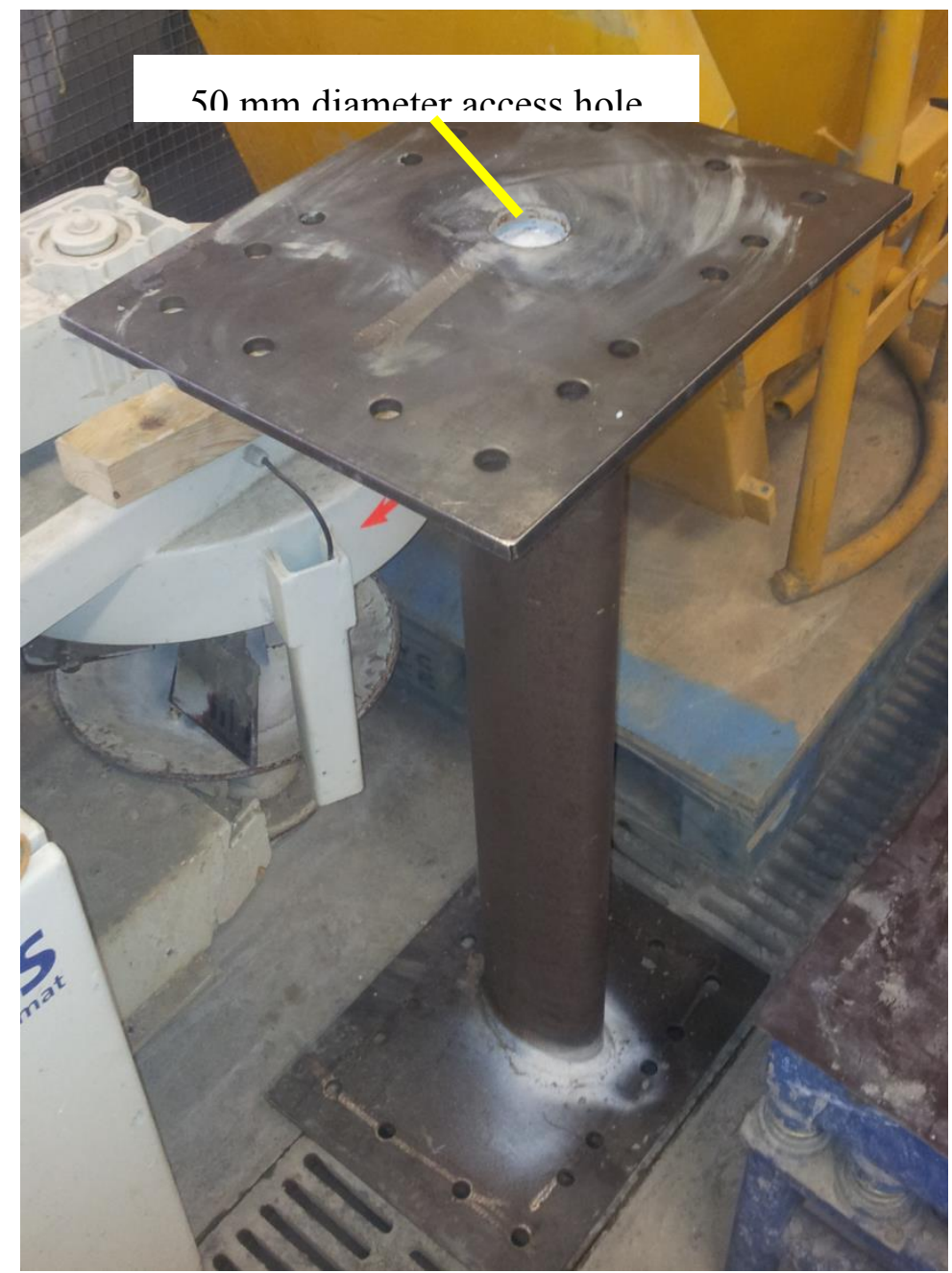

Figure 27

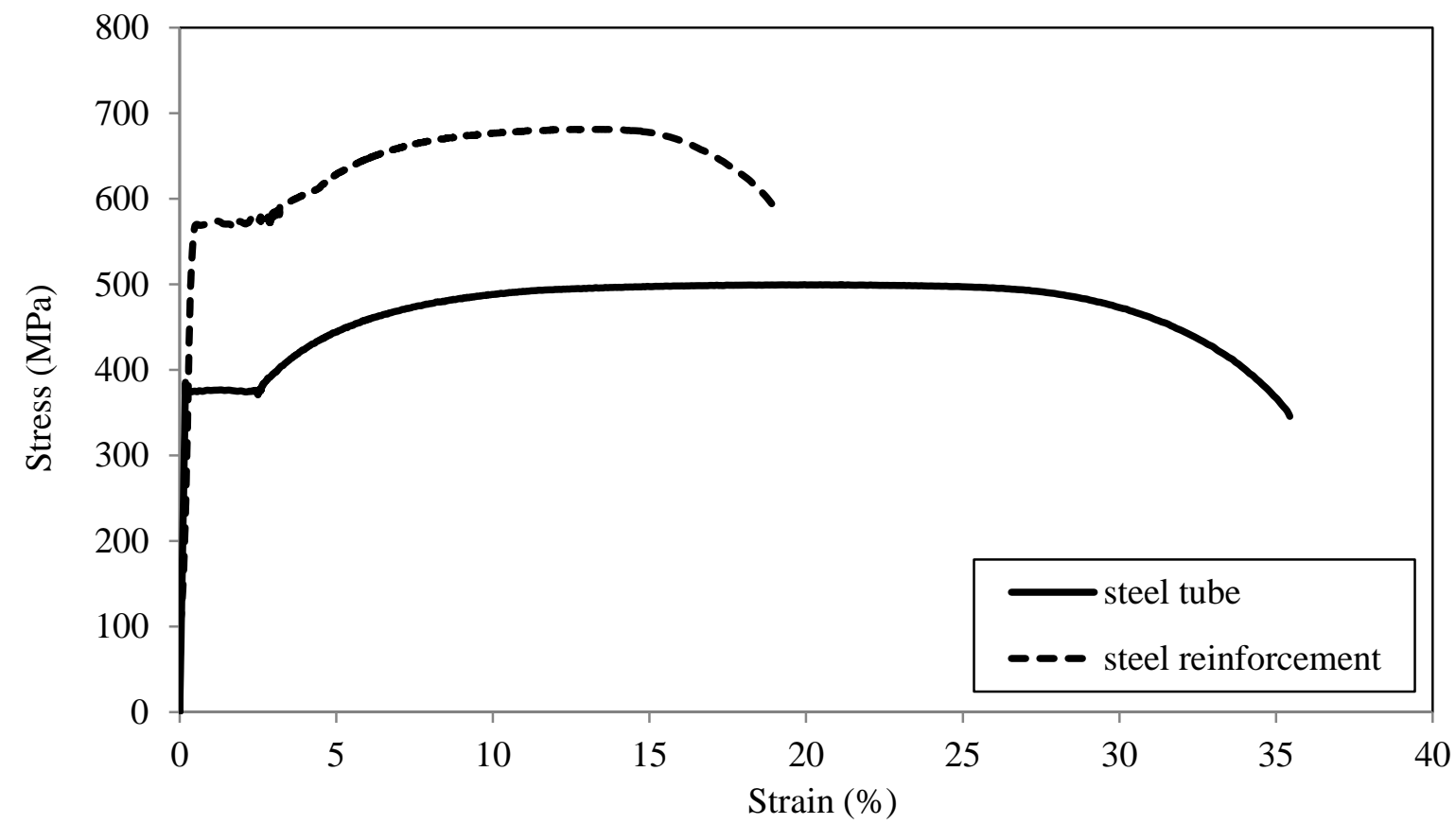

Figure 28 


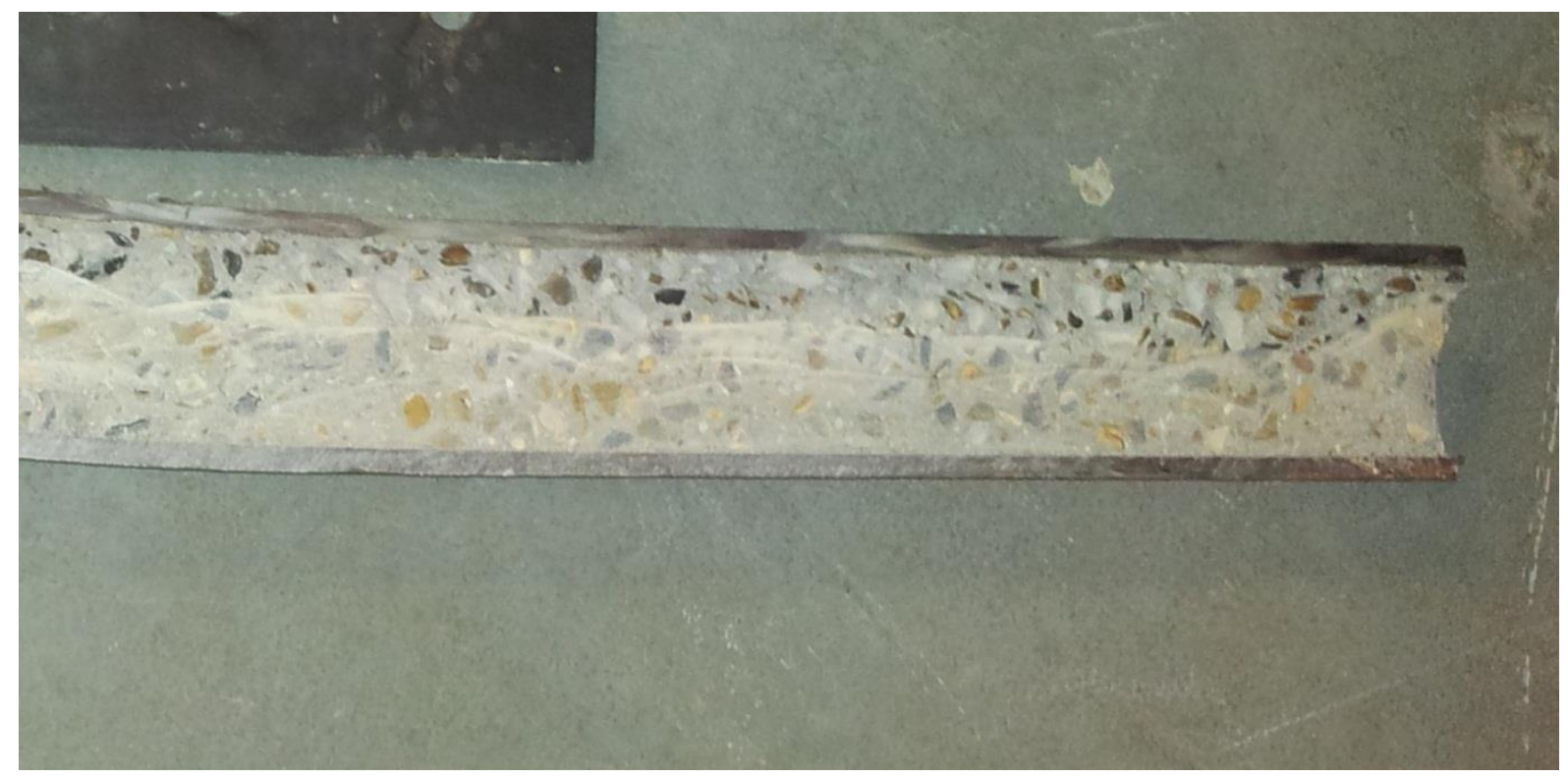

Figure 29

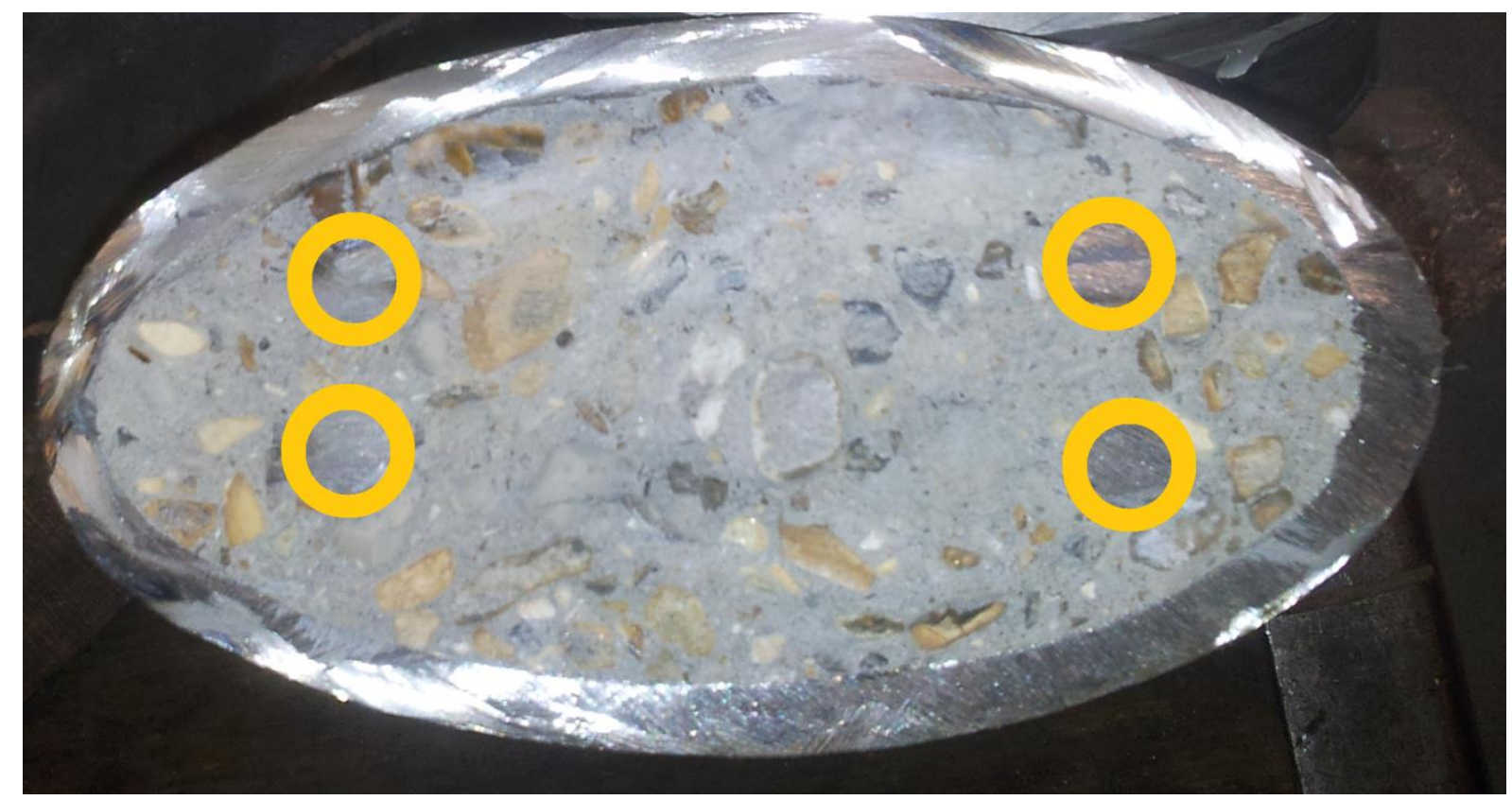

Figure 30 


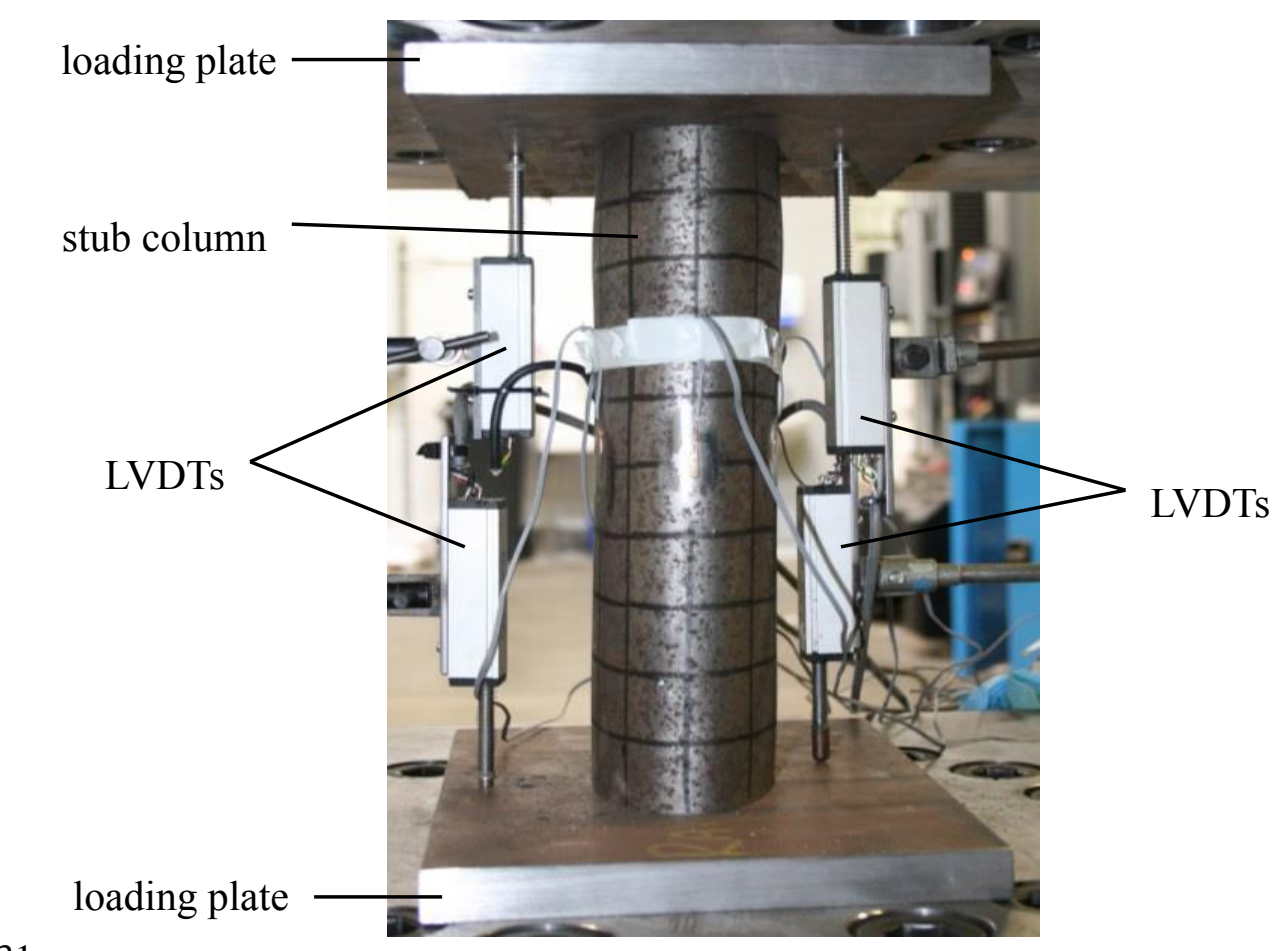

Figure 31

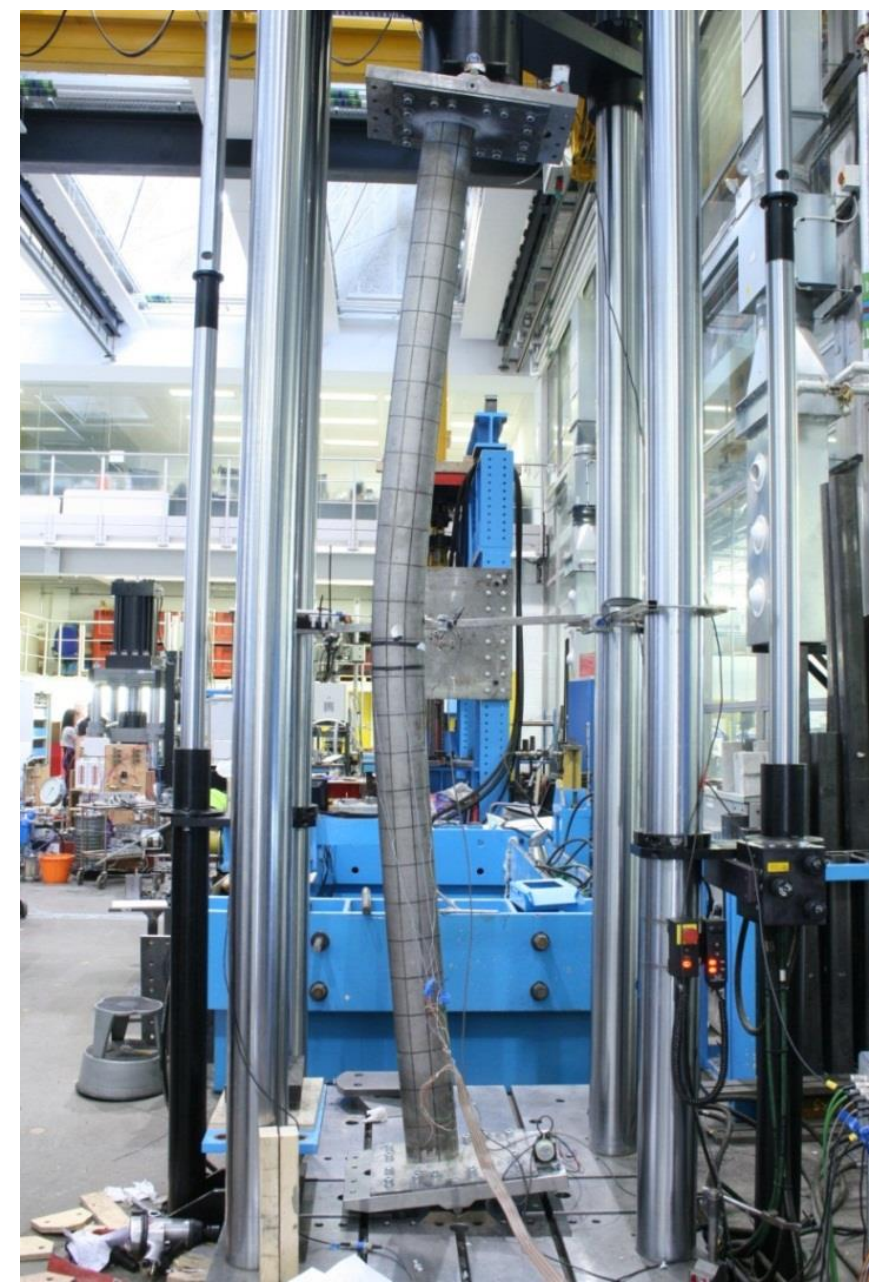

Figure 32 


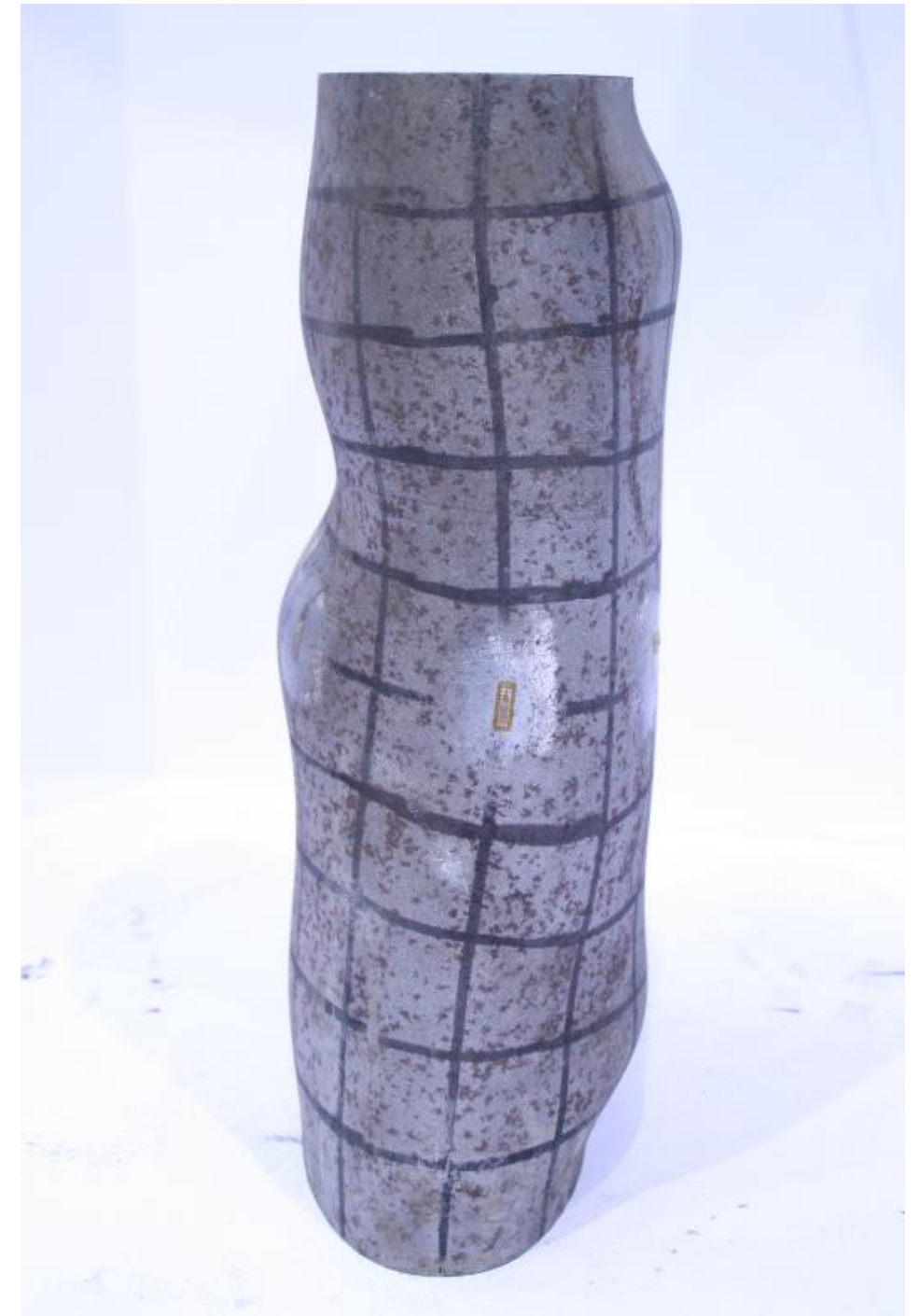

Figure 33 


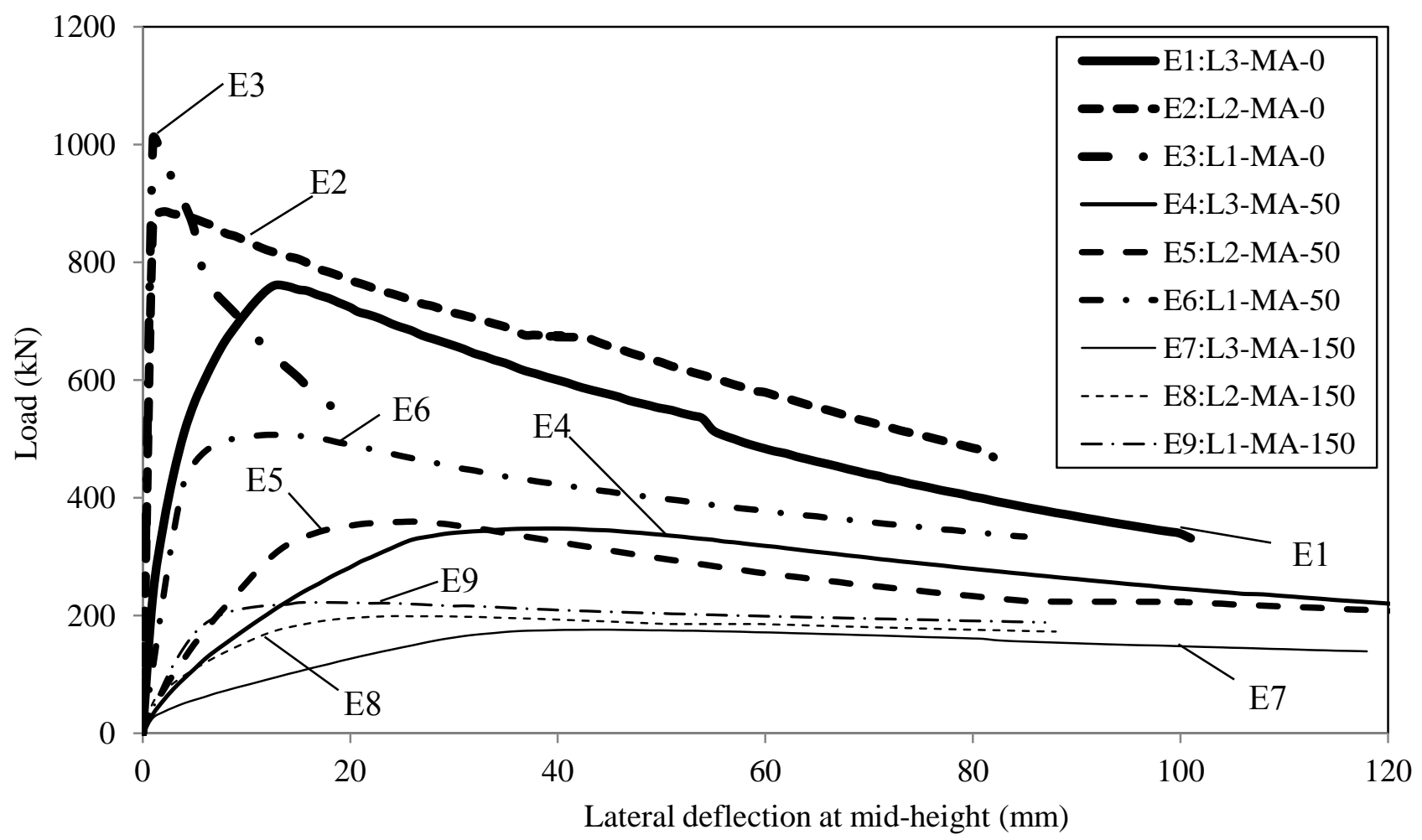

Figure 34

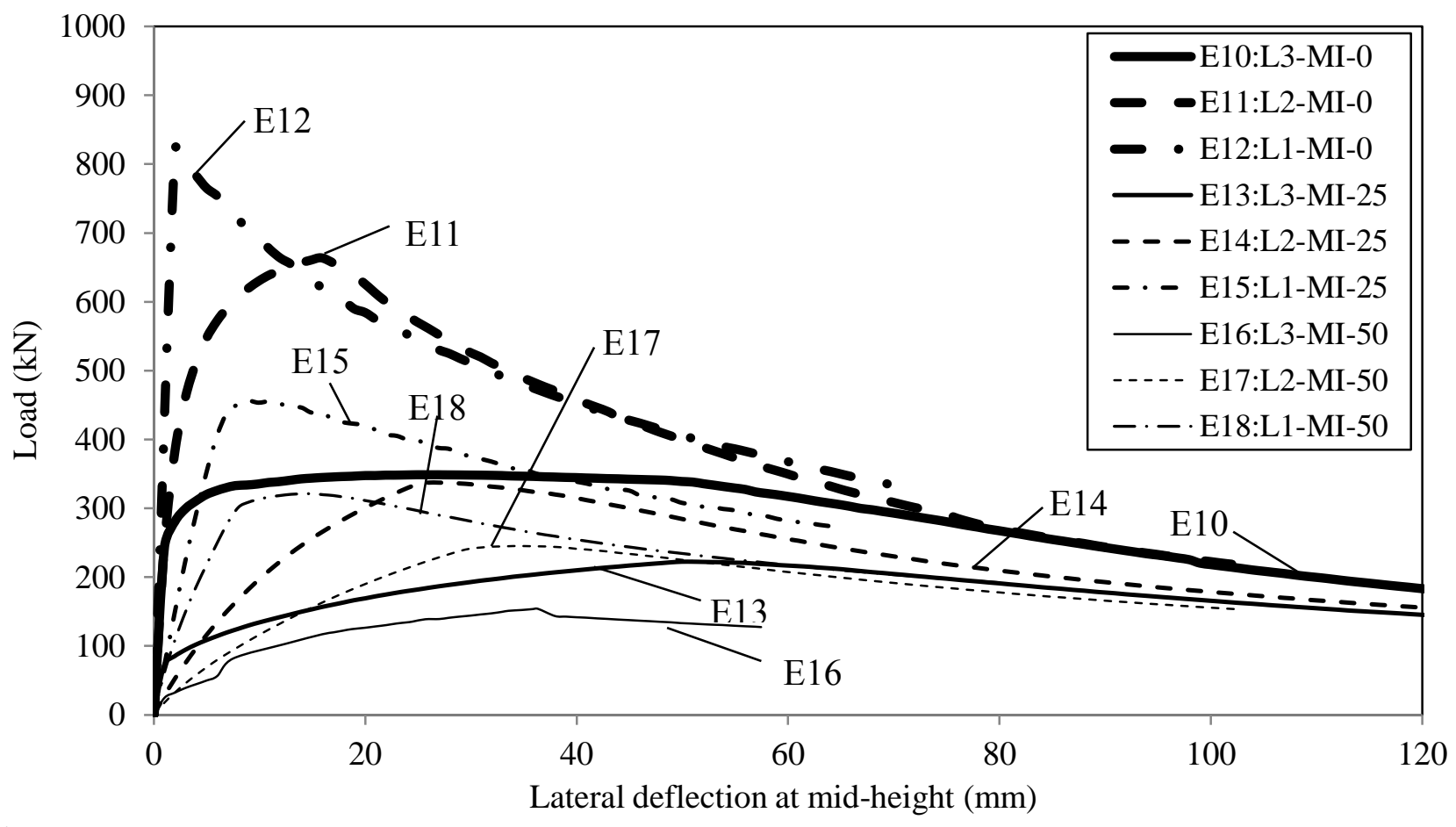

Figure 35 


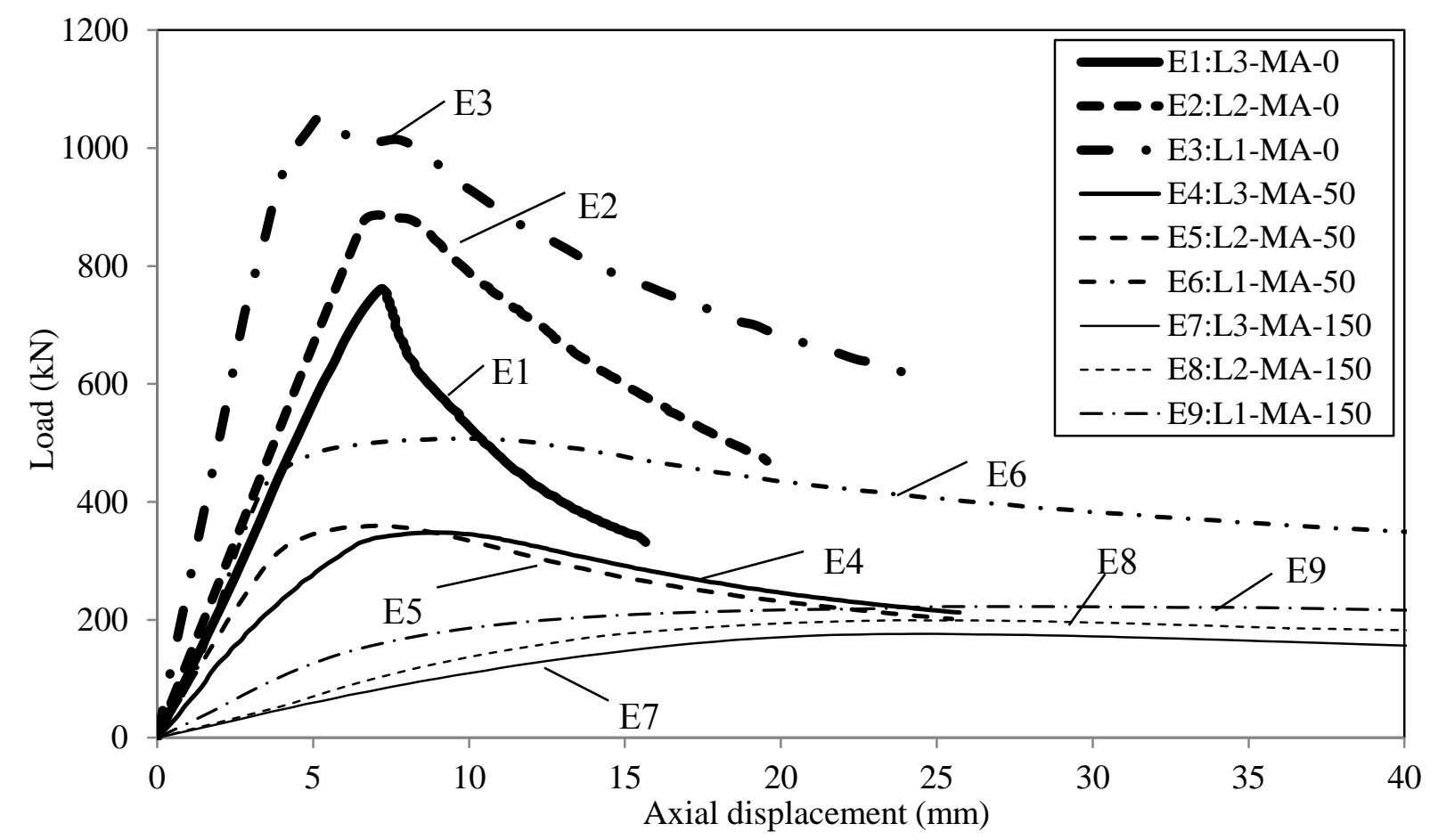

Figure 36

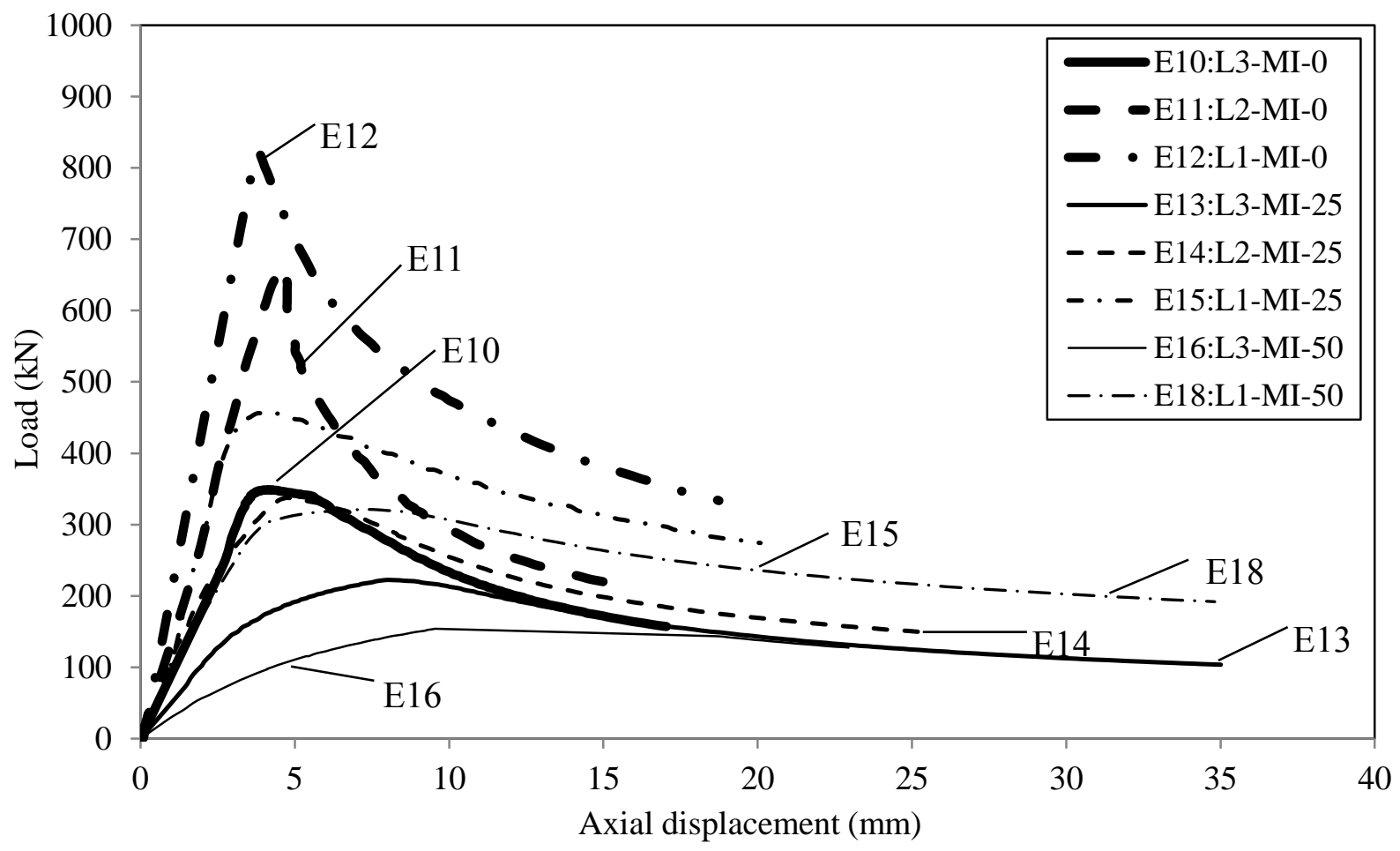

Figure 37 


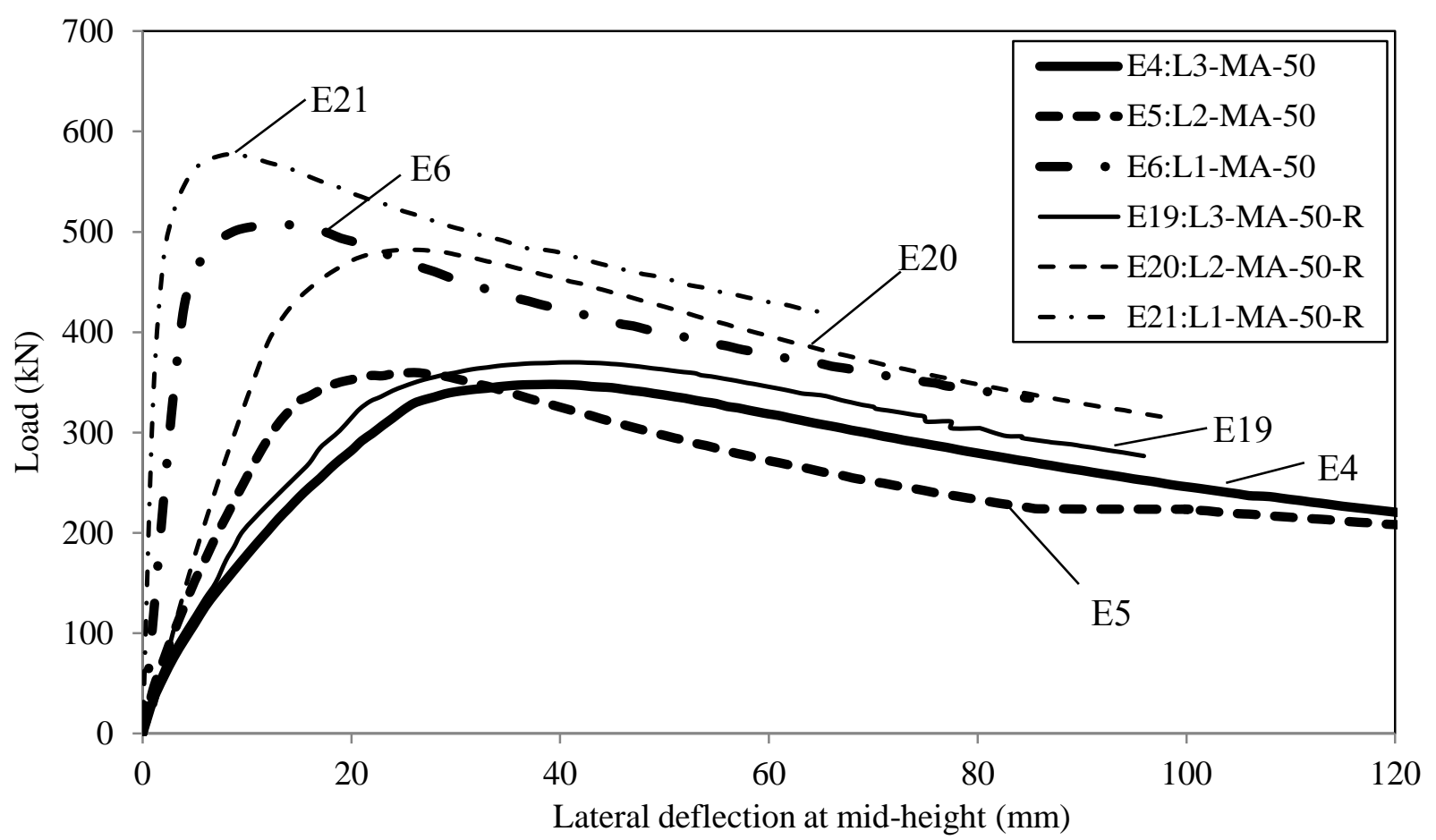

Figure 38

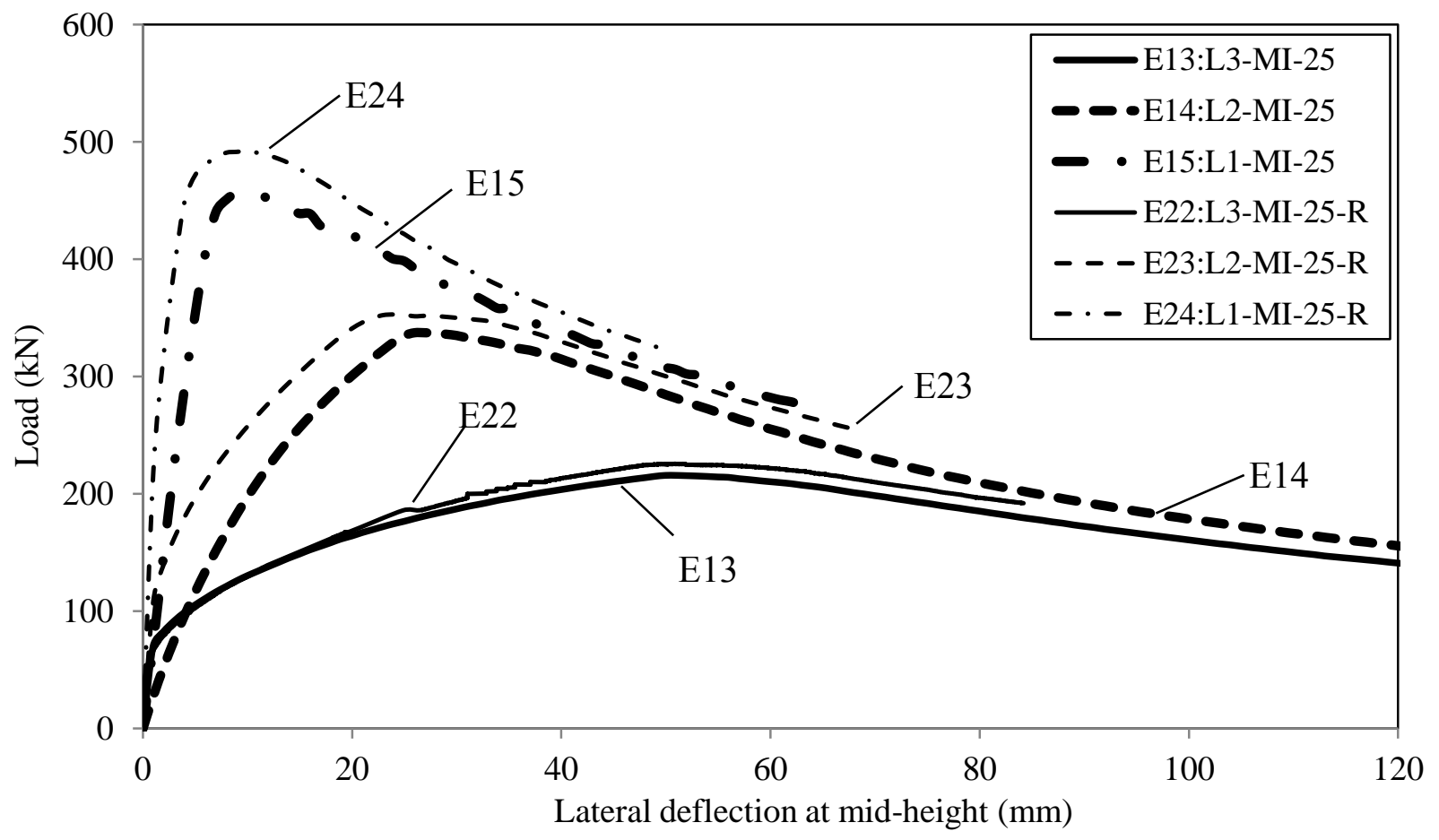

Figure 39 


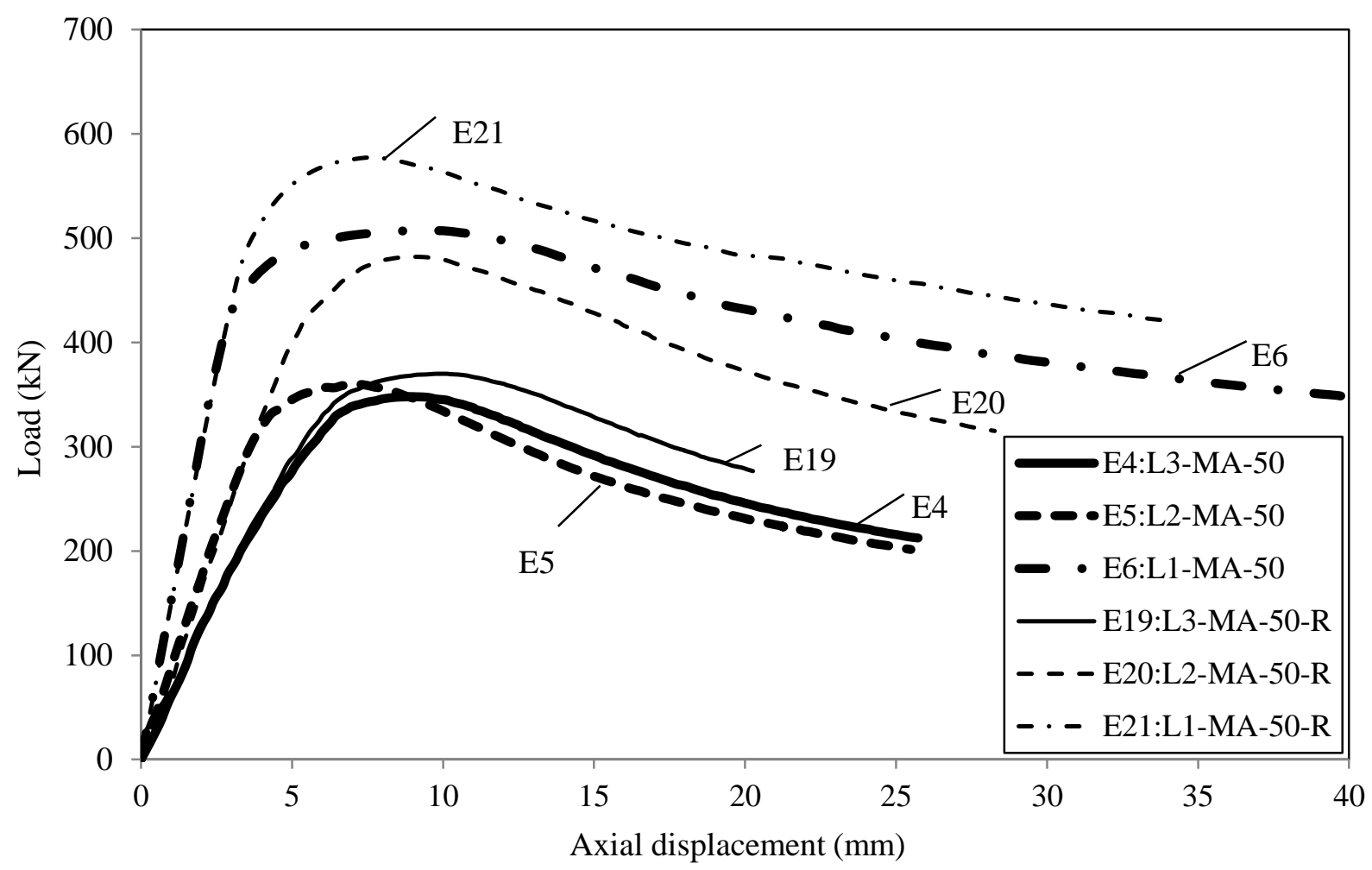

Figure 40

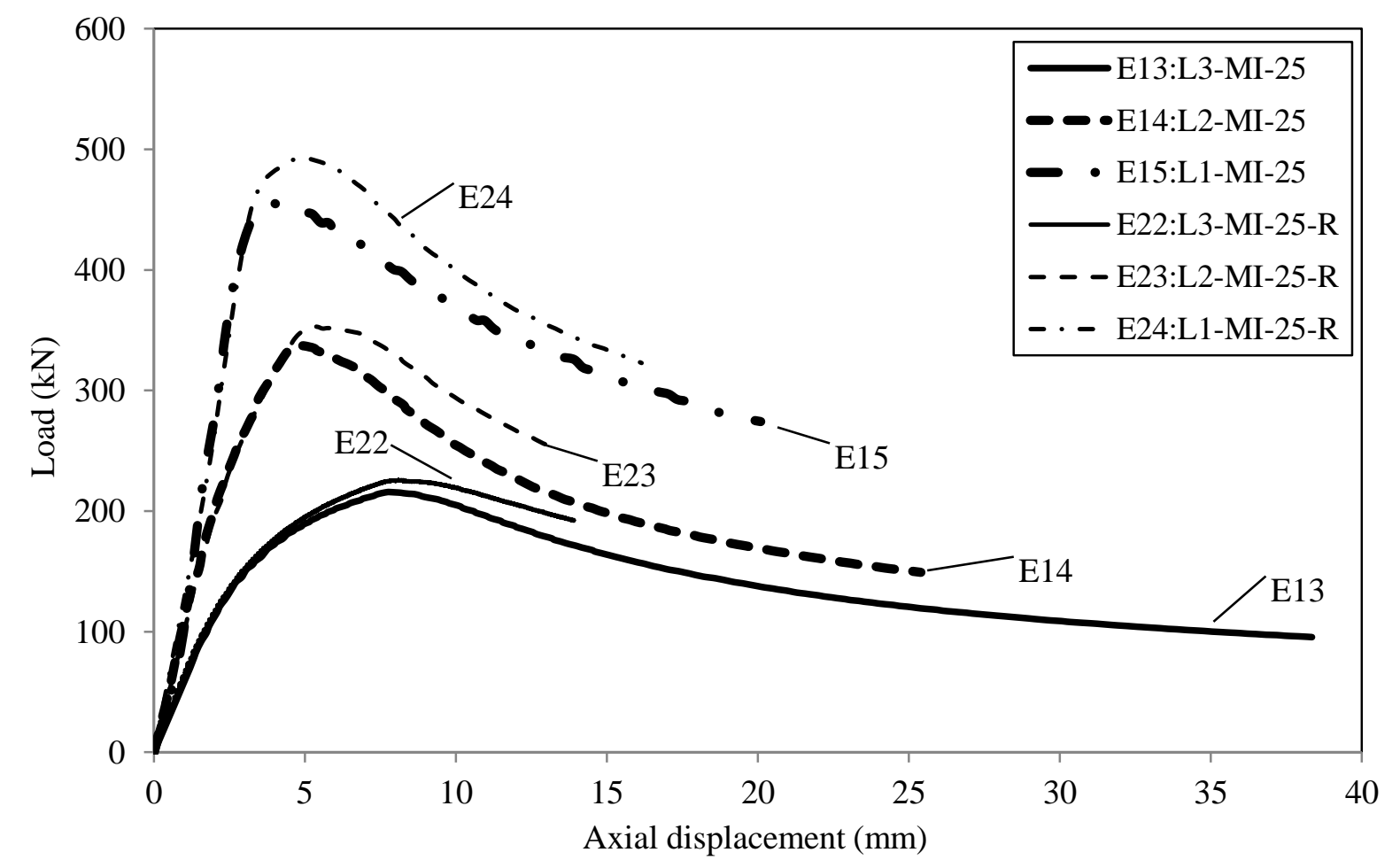

Figure 41 


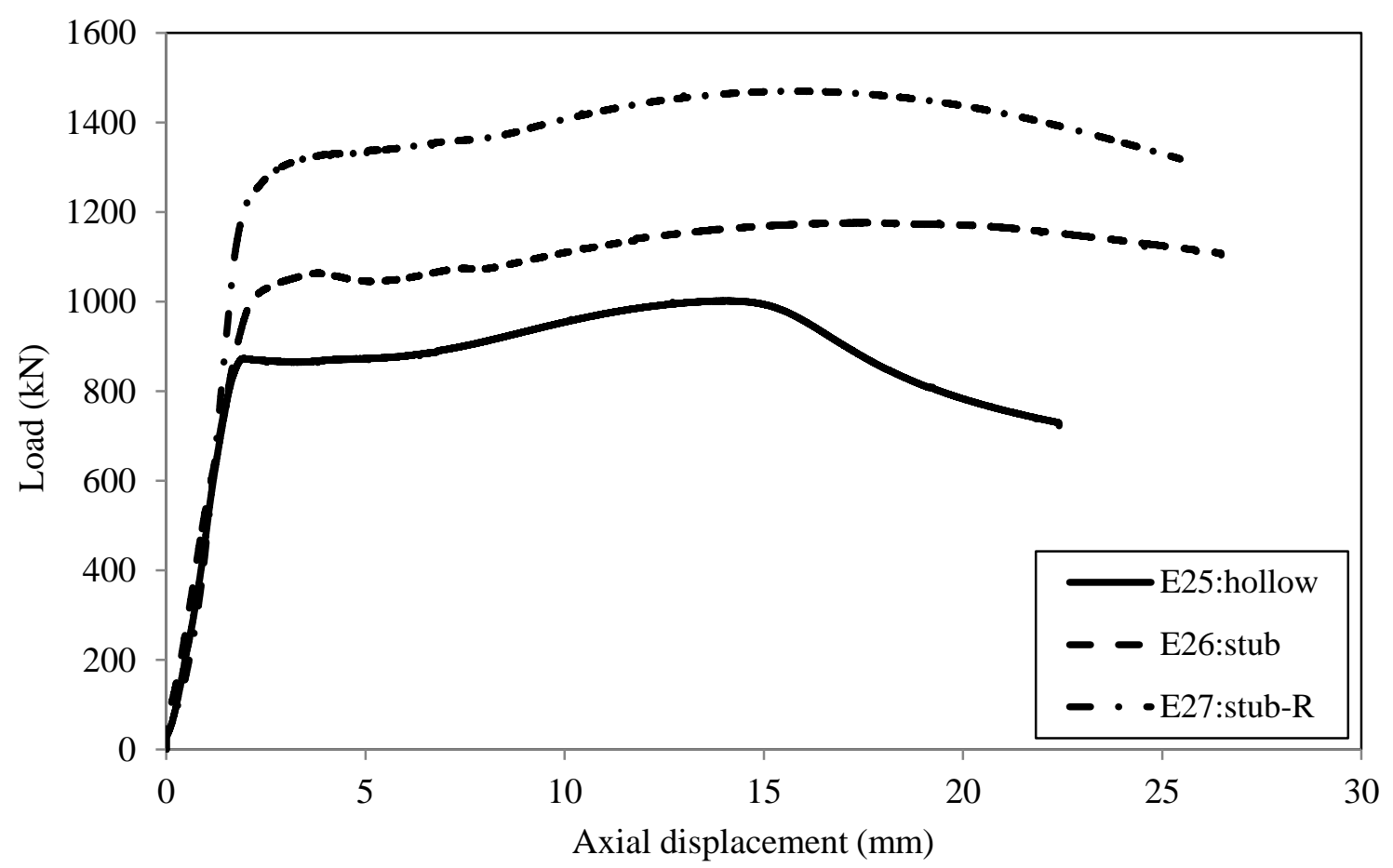

Figure 42

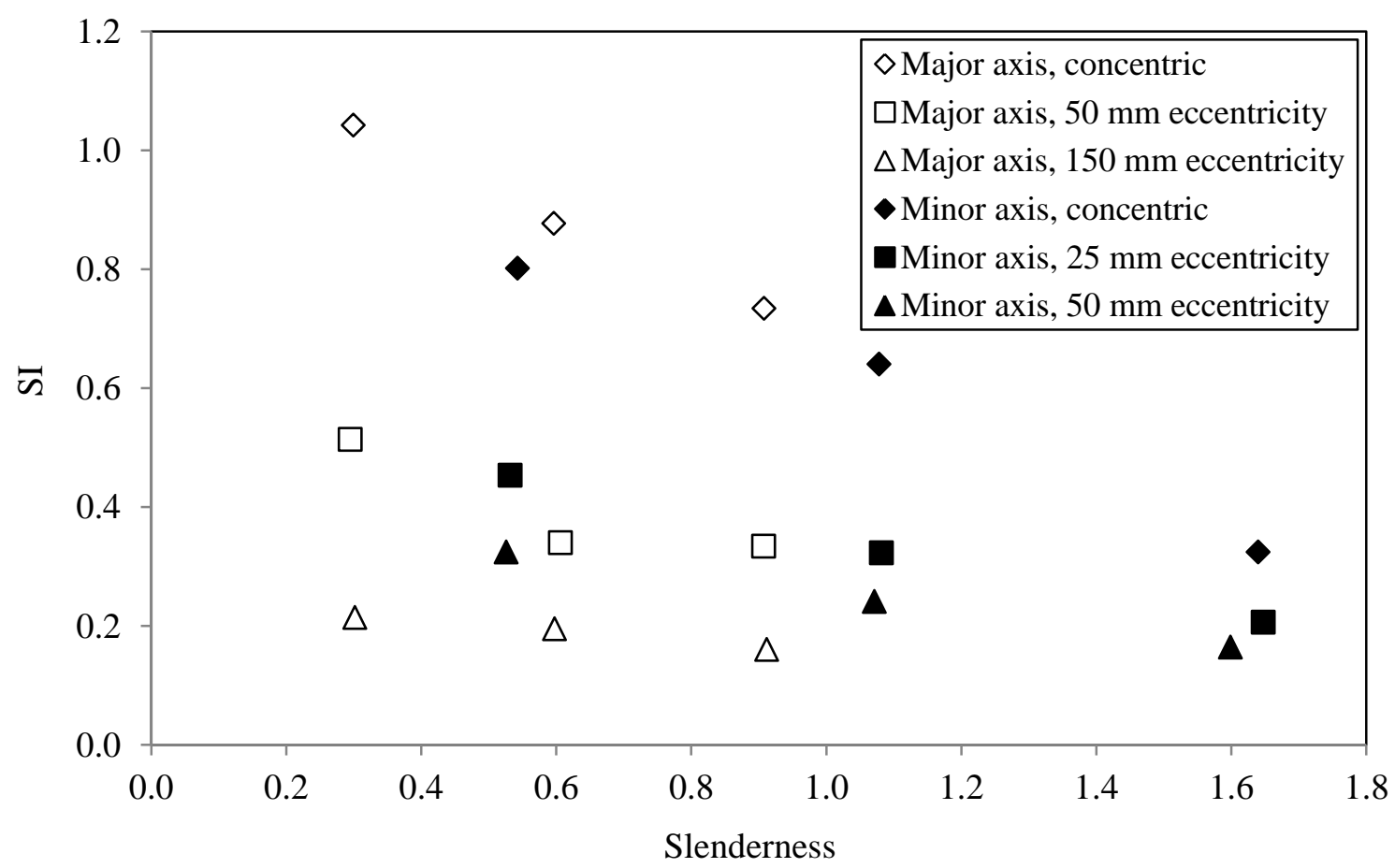

Figure 43 


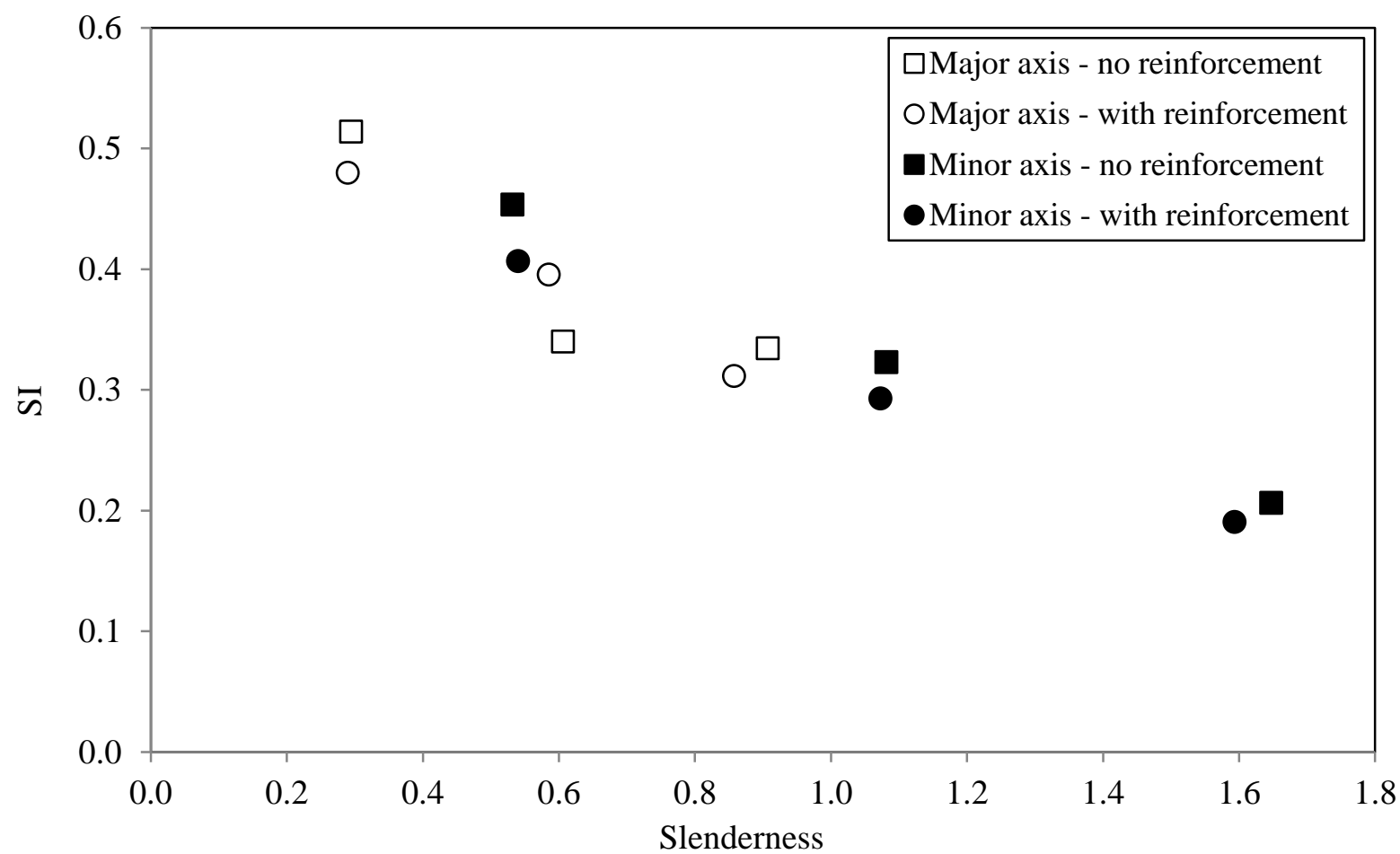

Figure 44

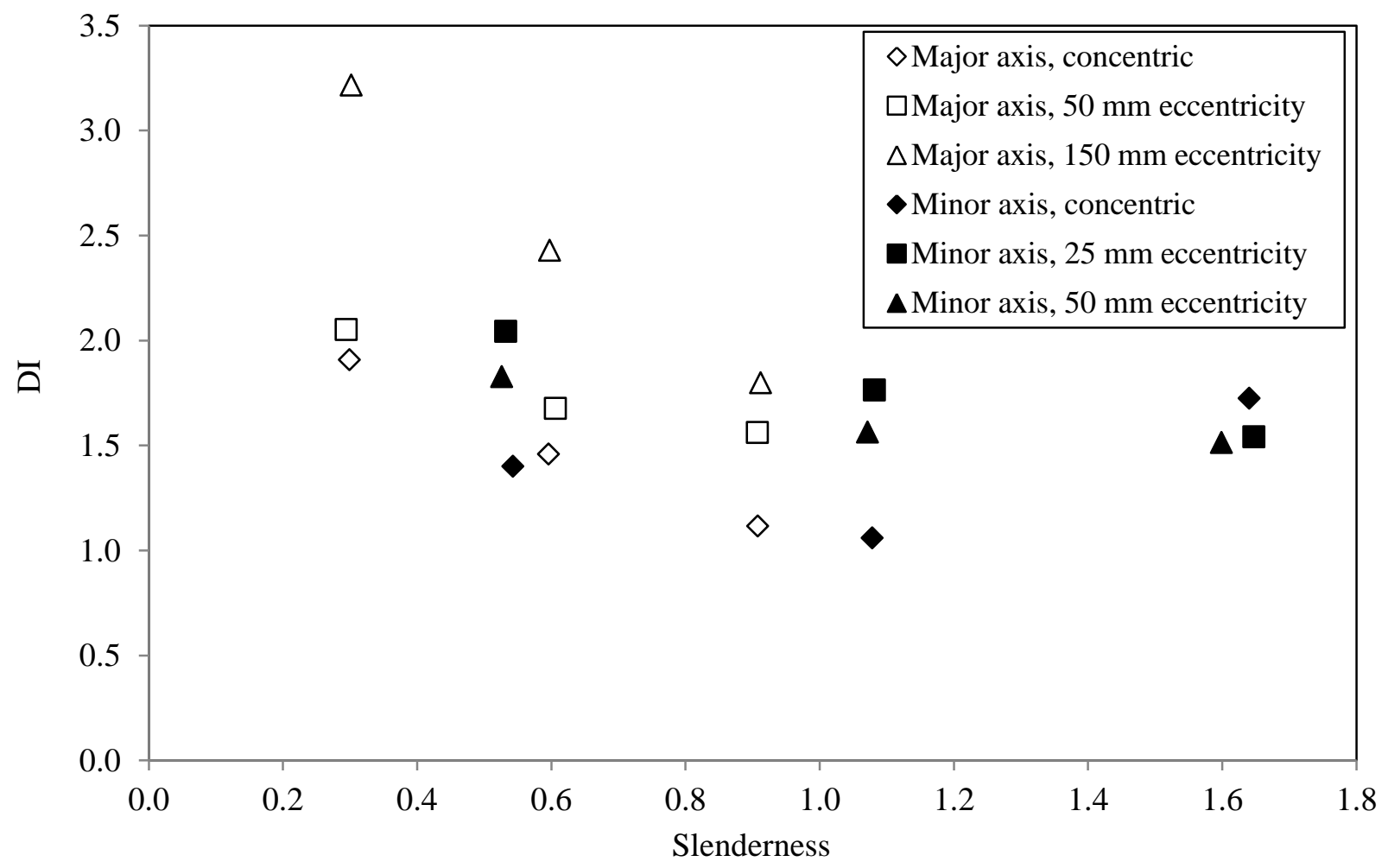

Figure 45 


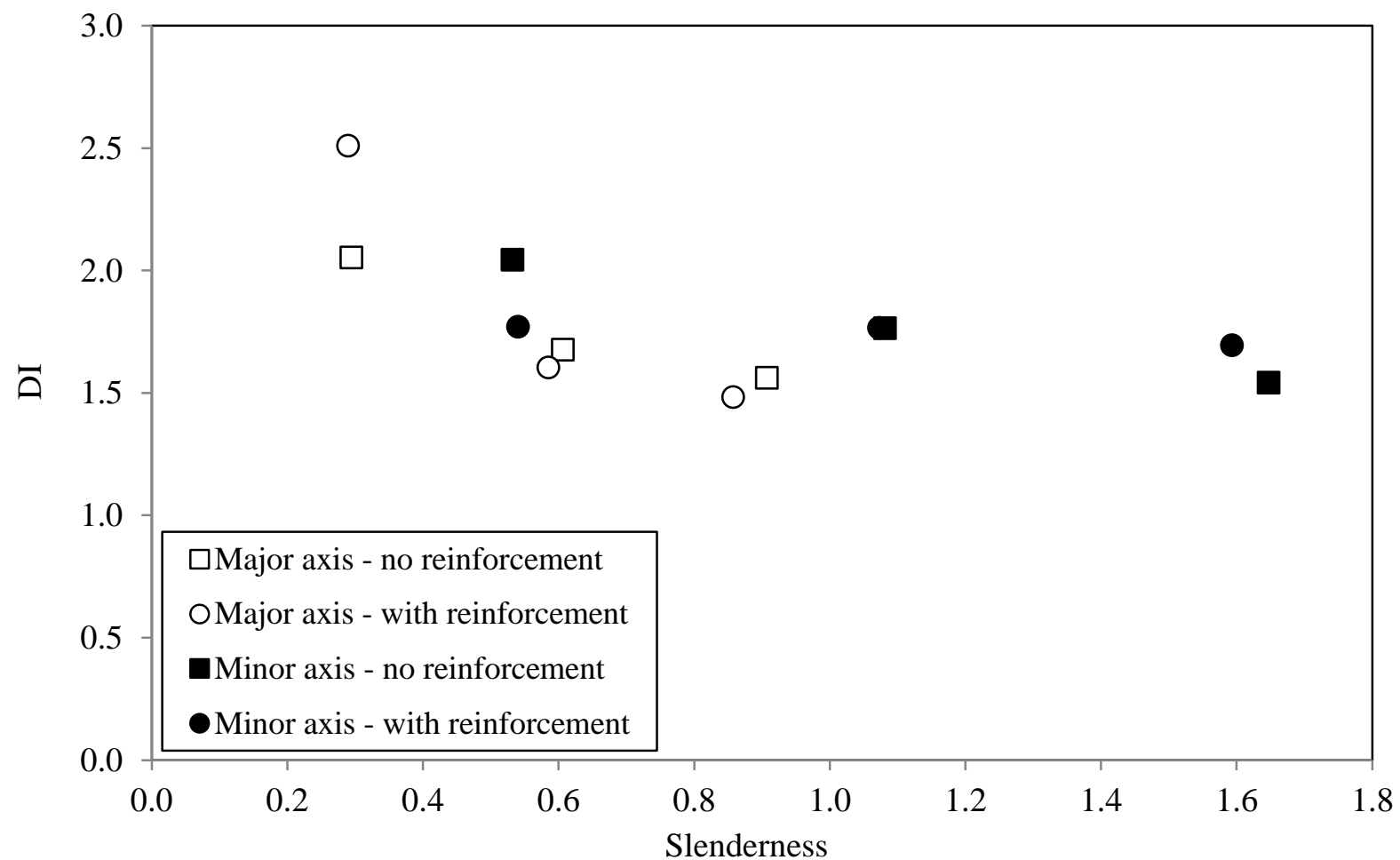

Figure 46

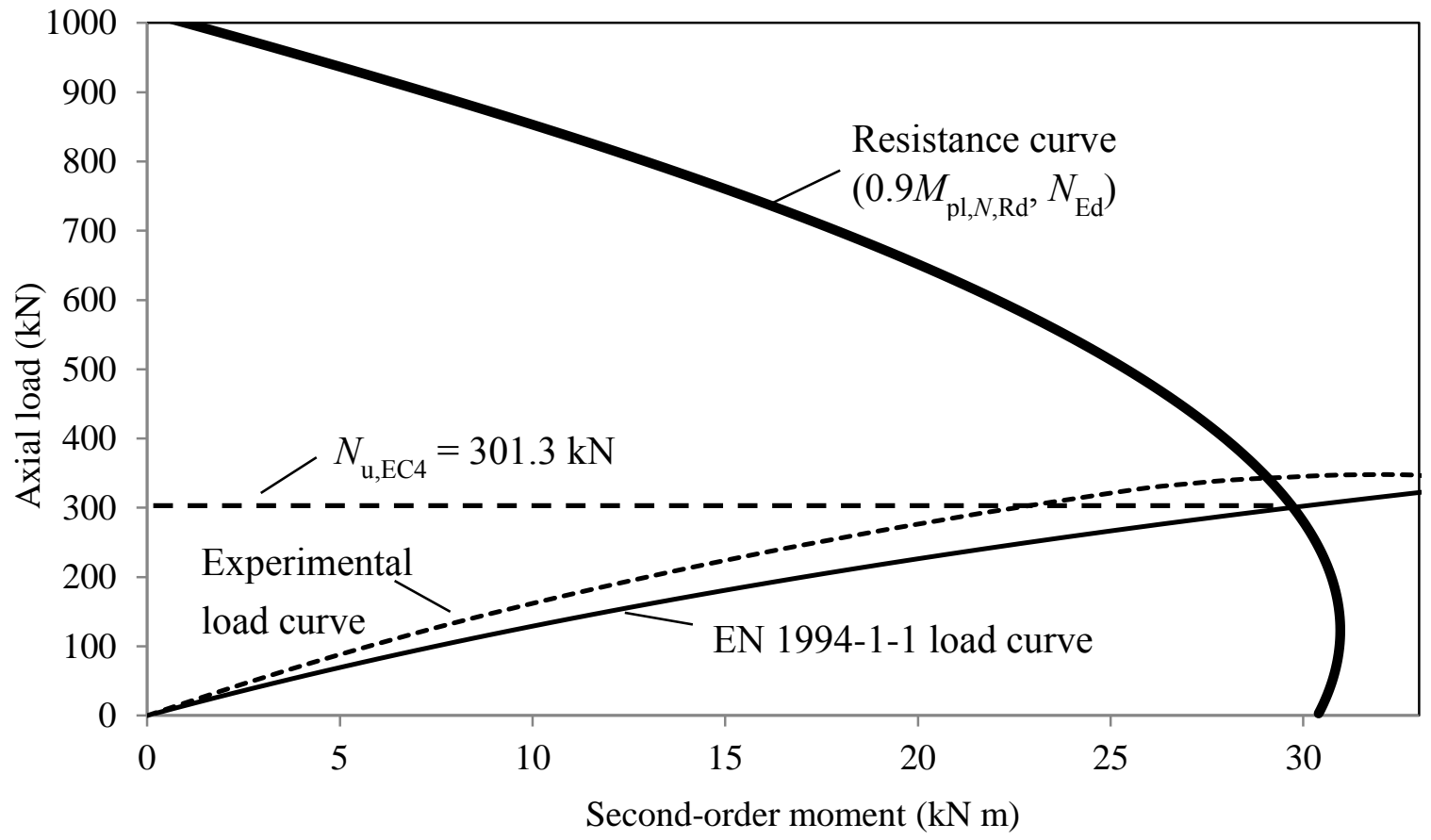

Figure 47 


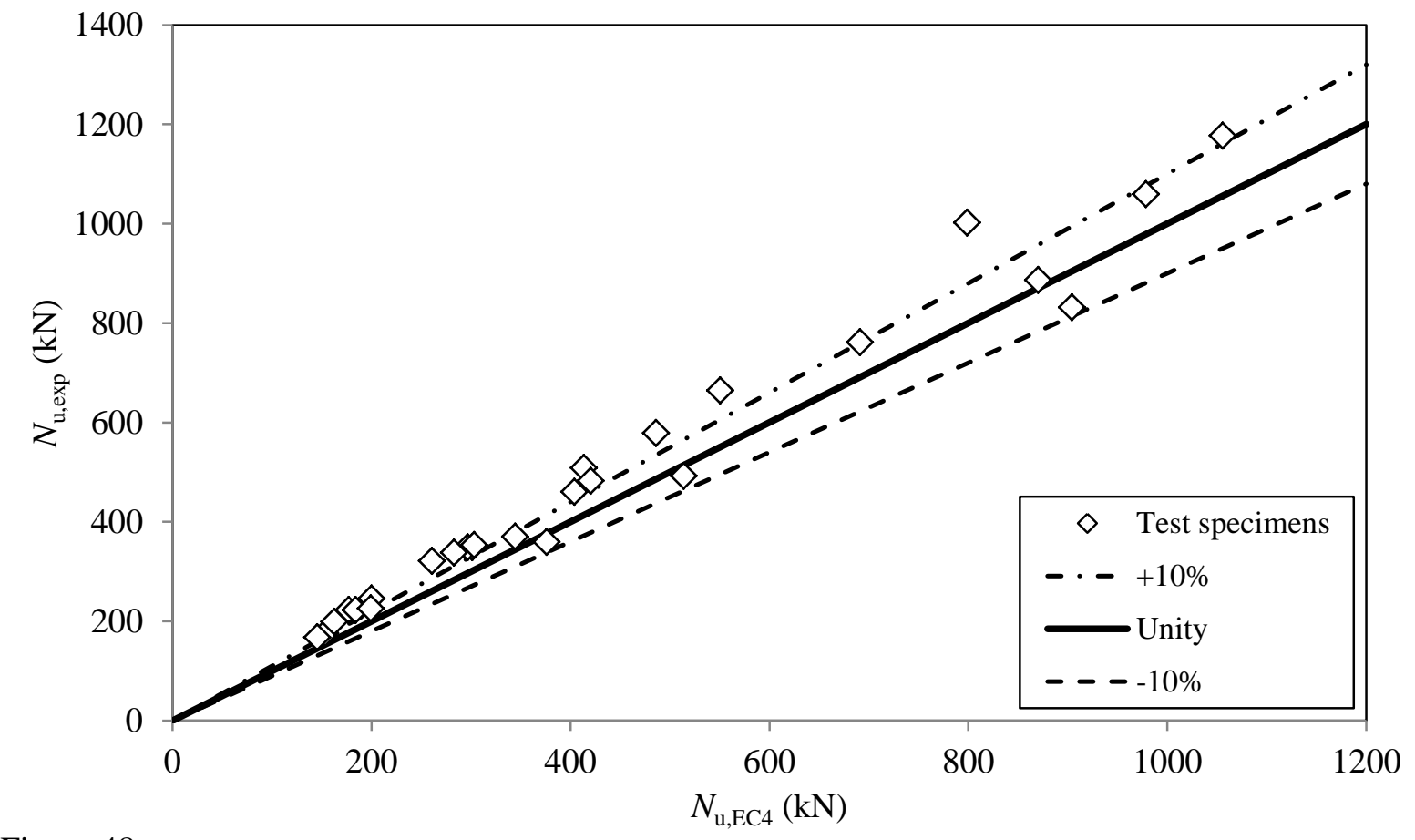

Figure 48 